This is the peer-reviewed version of the following article:

Peón, A., Robles, A., Blanco, B., Convertino, M., Thompson, P., \& Hawkins, A. et al. (2017). Reducing the Flexibility of Type II Dehydroquinase for Inhibition: A Fragment-Based Approach and Molecular Dynamics Study. Chemmedchem, 12(18), 1512-1524, which has been published in final form at https://doi.org/10.1002/cmdc.201700396.

This article may be used for non-commercial purposes in accordance with Wiley-VCH Terms and Conditions for Self-Archiving 


\title{
Reducing the Flexibility of Type II Dehydroquinase Enzyme for Inhibition - A Fragment-Based Approach and Molecular Dynamics Simulation Study
}

\author{
Antonio Peón,,${ }^{[\mathrm{a}]}$ Adrián Robles, ${ }^{[\mathrm{a}]}$ Beatriz Blanco,${ }^{[\mathrm{a}]}$ Marino Convertino, ${ }^{[\mathrm{b}, \overline{\mathrm{g}}]}$ Paul Thompson, ${ }^{[\mathrm{c}]}$ Alastair R. \\ Hawkins, ${ }^{[c]}$ Amedeo Caflisch, ${ }^{*[b]}$ and Concepción González-Bello*[a]
}

\begin{abstract}
A multidisciplinary approach was used to identify and optimize a quinazolinedione-based ligand that would reduce the flexibility of the substrate-covering loop (catalytic loop) of the type II dehydroquinase from Helicobacter pylori. This enzyme, which is essential for the survival of this bacterium, is involved in the biosynthesis of the aromatic amino acids. A computer-aided fragment-based protocol (ALTA) was first employed to identify the aromatic fragments able to block the interface pocket that separates two neighbor enzyme subunits and is located at the active site entrance. Chemical modification of its non-aromatic moiety through an olefin cross metathesis and Seebach's self-reproduction of chirality synthetic principle allowed the development of a quinazolinedione derivative that disables the catalytic loop plasticity, which is essential for the enzyme catalytic cycle. Molecular dynamics simulation studies revealed that the ligand would force the catalytic loop into an inappropriate arrangement for catalysis by strong interactions with the catalytic tyrosine and by expelling the essential arginine out of the active site.
\end{abstract}

\section{Introduction}

Although antibiotics are one of the most successful drugs in clinic that have saved millions of lives, many of them are nowadays ineffective in treating infections caused by resistant bacteria. ${ }^{1}$ This is a dramatic problem in people with a weak immune system or undergoing surgery, cancer chemotherapy, dialysis, etc. for which the treatment of secondary processes are crucial. One of the factors responsible for the actual resistant

[a] Dr. A. Peón, A. Robles, Dr. B. Blanco, Prof. C. González-Bello Centro Singular de Investigación en Química Biolóxica e Materiais Moleculares (CIQUS) and Departamento de Química Orgánica, Universidade de Santiago de Compostela,

calle Jenaro de la Fuente s/n, 15782 Santiago de Compostela,

Spain.

E-mail: concepcion.gonzalez.bello@usc.es

[b] Dr. M. Convertino, Prof. A. Caflisch

Department of Biochemistry,

University of Zurich,

$\mathrm{CH}-8057$ Zurich, Switzerland.

E-mail: caflisch@bioc.uzh.ch

[c] P. Thompson, Prof. A. R. Hawkins,

Institute of Cell and Molecular Biosciences, Medical School,

University of Newcastle upon Tyne,

Catherine Cookson Building, Framlington Place, Newcastle upon

Tyne NE2 4HH, UK.

Supporting information for this article is given via a link at the end of the document. levels is the fact that most of the antibiotics in clinical use target a reduced and the same type of bacterial targets and resistance to them are well known and spread worldwide. To this end, in recent years much research has been devoted to the identification of new and unexploited therapeutic targets involved in key processes for bacterial survival as well as the detailed insight of the basis of their behavior and the identification of compounds targeting them.

One of these interesting targets is the type II dehydroquinase (3dehydroquinate dehydratase, DHQ2, EC 4.2.1.10) that is the third enzyme of the shikimic acid pathway, through which erythrose-4-phosphate and phosphoenol pyruvate is converted into chorismic acid. The latter is the precursor of important aromatic metabolites such as the aromatic amino acids, folate cofactors, ubiquinone and vitamins $\mathrm{E}$ and $\mathrm{K} .{ }^{2} \mathrm{DHQ} 2$, which is encoded by the aroD/aro $Q$ gene, is an essential enzyme in Mycobacterium tuberculosis, the causative agent for tuberculosis, and Helicobacter pylori, which which is a major cause of gastric and duodenal ulcers and it has been classified as class I carcinogen by the International Agency of Research on Cancer (IARC) and World Health Organization (WHO).,

DHQ2 catalyzes the reversible dehydratation of 3-dehydroquinic acid (1) to form 3-dehydroshikimic acid (3) via the enolate intermediate 2 (Figure 1). ${ }^{5,6}$ Extensive biochemical, structural and $\mathrm{QM} / \mathrm{MM}$ studies revealed that the enzymatic reaction is initiated by an essential aspartate that deprotonates an essential tyrosine to afford the catalytic tyrosinate, which triggers the process. $^{5-7}$ The necessary reduction in $p K_{a}$ of the tyrosine is achieved by the proximity of two conserved arginine residues and a cation- $\pi$ interaction with an essential arginine. The final step is the acid-catalyzed elimination of the C1 hydroxyl group that is mediated by the conserved histidine acting as a proton donor.

Two of the three catalytic residues, Tyr22 and Arg17 for H. pylori DHQ2, are located in the substrate-covering loop (catalytic loop) that closes the active site after substrate binding (Figure 1A). It has been shown that the arrangement of the catalytic loop required for catalysis has: (1) the side chains of the tyrosine and arginine residues pointing towards the active site; and (2) a cation- $\pi$ interaction between the catalytic residues. ${ }^{5}$ We believe that targeting the loop plasticity is a good strategy for inhibitor design since the motion of this loop is an essential process for the DHQ2 catalytic cycle. ${ }^{5,8}$ We became therefore interested in designing ligands able of altering the flexibility of the loop by compounds structurally different from previously reported ones, which are mainly based on the mechanism of action. ${ }^{7}$ These reported inhibitors are either mimics of the enol intermediate 2 , 
compounds $4-5,{ }^{9}$ or substrate analogs, compounds $6^{10}$ (Figure 1D). More recently, several 3-nitrobenzylgallate-based analogs 7 have been described, which incorporate relevant aromatic moieties previously identified by structural and biological studies. ${ }^{11}$ Remarkably, in the crystal structure of DHQ2 in complex with the most potent inhibitors is observed that the aromatic moiety present in their structure block the entrance of the essential arginine side chain into the active site and cause an important change in the appropriate arrangement and flexibility of the substrate-covering loop. ${ }^{12}$ These aromatic moieties are located in the interface pocket, which separates two neighbor subunits of the enzyme and is located at the entrance of the active site. DHQ2 is a dodecamer formed from a tetramer of trimers, a trimer being the minimum catalytic unit of the enzyme. ${ }^{13}$ QSAR studies also revealed that this pocket is key for the efficacy and specificity of inhibitors. ${ }^{14,15}$

In particular, we aimed for ligands that would either stabilize the closed form avoiding the entrance of the substrate or the open conformation providing a widely exposed active site. For our goal, we took into account: (1) our previous studies on the motion of the catalytic loop during product release pinpointed by Molecular Dynamic (MD) simulation studies of the product enzyme complex (Figure 1B), ${ }^{5}$ (2) the loop conformational changes observed in the crystal structures of DHQ2 from $M$. tuberculosis (Mt-DHQ2) and $H$. pylori (Hp-DHQ2) in complex with some of the most potent reported inhibitors, ${ }^{6}$ and (3) the well stablished advantages of the fragment-based approaches as will be discussed below. ${ }^{16-25}$
A

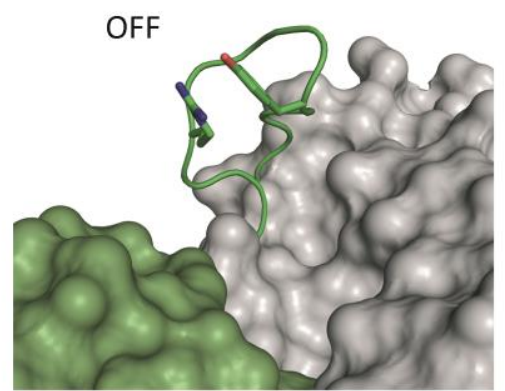

open loop

B

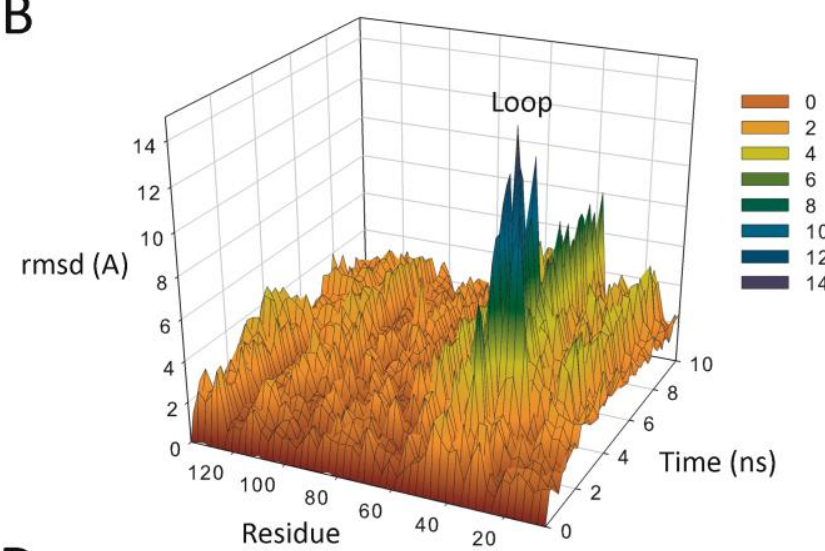

D<smiles>[R]C1=C[C@@](O)(C(=O)O)C[C@H](O)[C@@H]1O</smiles>

4<smiles>[R]C1=C([R])[C@](O)(C(=O)O)C[C@H](O)[C@@H]1O</smiles>

5
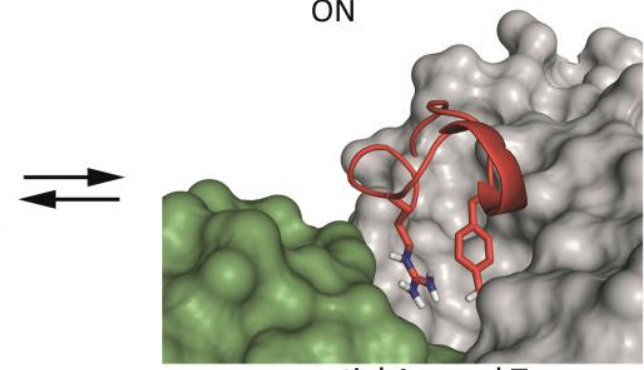

essential Arg and Tyr

inside active site (cation- $\pi$ )

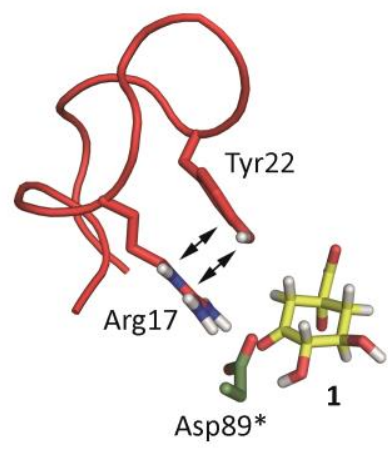

C

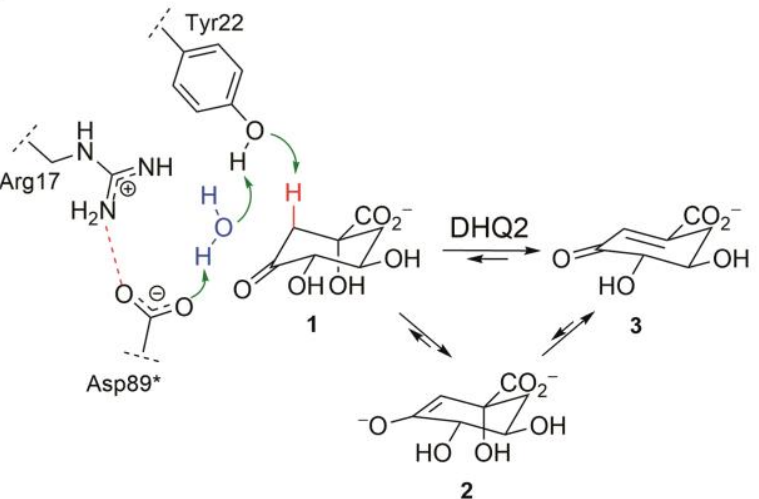

2
${ }^{1} \mathrm{R}=$ aryl, alkylaryl, alkyloxyaryl, alkinylaryl, alkenylaryl;

${ }^{2} \mathrm{R}=\mathrm{H}$, alkylaryl; $\mathrm{Ar}=$ aryl; $\mathrm{X}=\mathrm{O}, \mathrm{NH} ; \mathrm{Z}=\mathrm{H}, \mathrm{OH}$;

$\mathrm{W}=\mathrm{OH}, \mathrm{CO}_{2} \mathrm{H}$

6

Figure 1 (A) Schematic representation of the DHQ2 enzyme motion required for catalysis. Note the cation-m interaction between the essential tyrosine and arginine side chains that are required for catalysis. Both residues must be also pointing towards the active site. Only two chains of the catalytic trimer are shown for clarity. (B) RMSD plot for the protein backbone ( $\mathrm{Ca}, \mathrm{C}, \mathrm{N}$, and $\mathrm{O}$ atoms) calculated per residue in the DHQ2/3 complex obtained from MD simulations studies of the product release (DHQ2/3 enzyme complex). ${ }^{5}$ Note how the loop undergoes a large conformational change during product release whereas no significant changes are observed in the rest of the protein. (C) Enzymatic conversion of 3-dehydroquinic acid (1) to 3-dehydroshikimic acid (3) catalyzed by DHQ2. The reaction proceeds via the enol intermediate 2. (D) Selected examples of DHQ2 inhibitors. ${ }^{9-1}$ 
We aim to identify inhibitors containing drug-like entities that might facilitate the entrance into the bacterium cell in which the aromatic fragments would be located in the interface pocket to block the active site entrance. For this purpose, fragment-based screening is nowadays a wide accepted technique to identify relatively simple hit-compounds that possess a high binding affinity per heavy atom, and thus are ideal compounds for optimization into clinical candidates with good drug-like properties. ${ }^{16-25}$ This technique has emerged as an important alternative to high-throughput screening, ${ }^{24-25}$ because it has the advantage that incorporates the structural information ${ }^{26}$ of the target to preselect the molecules that are most likely to show binding and inhibitory activity. The available experimental knowledge of known inhibitors is incorporated by using pharmacophore constraints to preselect compounds for docking and therefore reducing computation times. Computer-aided fragment-based approaches are being increasingly proven as a successful means of generating novel hits for drug discovery programs. ${ }^{27}$ In this context, the Anchor-based Library Tailoring screening Approach (ALTA), which was developed in 2008 by Caflisch et al., ${ }^{28}$ has proven to be very efficient for the discovery of novel inhibitors of a variety of targets. For instance, it has been successfully applied to the discovery of inhibitors of tyrosine kinase erythropoietin producing human hepatocellular carcinoma receptor $\mathrm{B} 4,{ }^{28-29}$ of the West Nile virus NS3 protease ${ }^{30}$ cathepsin $\mathrm{B},{ }^{31}$ the human cyclin-dependent kinase $2^{32}$ and several human bromodomains ${ }^{33}$. The essential element of the ALTA method is the use of optimally docked small fragments to select from a large library of compounds only those that have one (or more) of the top-ranking fragments.

Here, we present the computer-aided fragment-based identification of reversible competitive inhibitors of a recognized target for antibiotic drug discovery, $H p$-DHQ2. The synthesis of the identified potential compounds and their inhibitory activity are also provided. Moreover, chemical modifications on the most active compound obtained in this study were also explored for further optimization. We provide evidence based on Molecular Dynamics (MD) simulation studies that our inhibitors reduce the plasticity of the catalytic loop by blocking key residues for the catalysis.

\section{Results and Discussion}

\section{Fragment-based Identification of Ligands}

The subset "clean-leads" of the ZINC database ${ }^{34}$ with about 1.5 million compounds was chosen for this study. The computeraided fragment-based approach used, ALTA, involves four consecutive steps (Figure 2): (1) automatic decomposition of each molecule of the chemical library into fragments using the program DAIM (Decomposition And Identification of Molecules); ${ }^{35}$ (2) fragment docking using SEED (Solvation Energy for Exhaustive Docking) for selection and ranking of the fragments, ${ }^{36}$ (3) substructure search of the ALTA-selected fragments into the chemical library for initial selection of potential ligands; and (4) flexible docking of each selected compound using the best poses of its fragments as anchors for final compound selection and ranking. This is carried out using FFLD $^{37}$ (Fast Flexible Ligand Docking) and $\mathrm{CHARMM}^{34}$ for the energy minimization of the enzyme-ligand resulting complex. Evaluation of the binding free energy of multiple poses of each compound makes use of the LIECE (Linear Interaction Energy with Continuum Electrostatics) method. ${ }^{39}$

To discard at an early stage fragments that are unlikely to bind, several pharmacophores constraints were used. In particular, considering that the active site of DHQ2 has several residues capable of recognizing bidentate groups such as carboxylates or sulfonamides, a filtering step discarded all compounds devoid of these functional groups. It was also considered that compounds should have a maximum of 10 rotatable bonds, between 2 to 6 acceptor groups, $\leq 3$ donor groups and a total number of hydrogen-bond acceptor and donor $\leq 10$. As a consequence, the chemical library was reduced to 239.779 compounds from which DAIM extracted 61.549 candidate fragments.

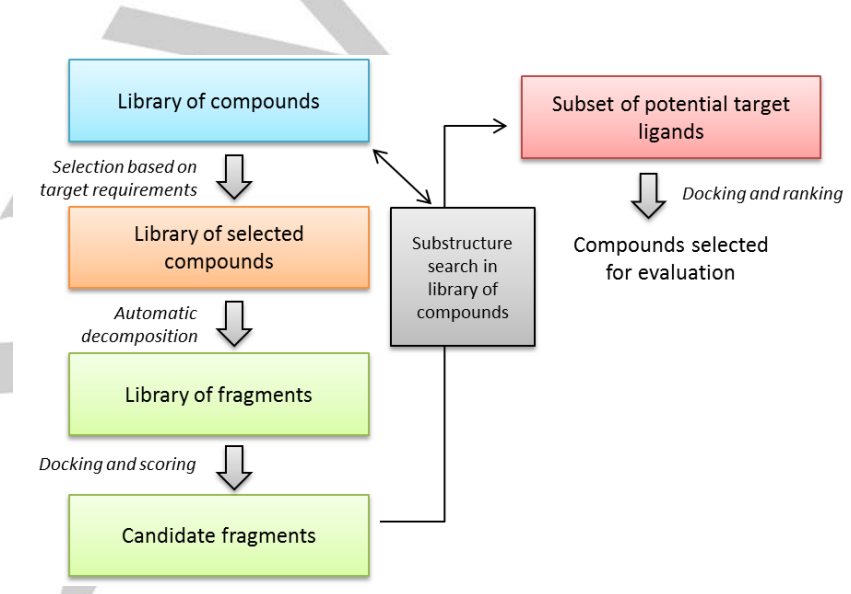

Figure 2 Graphical representation of the workflow of ALTA procedure.

Docking was carried out using the previously reported enzyme structure of $H p-D H Q 2$ in complex with $(1 R, 4 S, 5 R)-1,4,5$ trihydroxy-3-[(5-methyl-1-benzothiophen-2-yl)methoxy]cyclohex2-ene-1-carboxylic acid (4a, ${ }^{1} \mathrm{R}=(5$-methyl-1-benzothiophen-2$\mathrm{yl}$ )methoxy), PDB code $2 \mathrm{WKS}) .^{9 \mathrm{~m}}$ This crystal structure was chosen because it has an inappropriate conformation of the substrate-covering loop for catalysis. Thus, the aromatic moiety in $4 a$ expels the side chain of the essential Arg17 out of the active site and, under this arrangement the enzyme is efficiently inhibited. After fragment docking, the library of fragments was reduced to 10.712 candidate fragments. Using all these fragments as queries a subset of 30.309 compounds from the initial library was generated. After flexible docking of each molecule of the library using the best poses of its fragments as anchors, the best 50 top-ranking compounds were selected (Table S1). The first two compounds and seven of remaining ones, which were selected based on structural considerations of the key interactions with the enzyme, were chosen for biological evaluation (Figure 3). Compounds $\mathbf{8}$ and 15-16 were obtained from commercial sources and compounds 9-14 were 
synthesized using standard procedures (see a detailed description in the Supporting Information).

\section{Inhibition Activity of Compounds 8-16}

The potential DHQ2 ligands identified by ALTA-approach, compounds 8-16, were assayed in the presence of 3dehydroquinic acid (1) for their inhibitory properties against $\mathrm{Hp}$ DHQ2. The inhibition data are summarized in Table 1. In general, these compounds were found to be reversible competitive inhibitors of the enzyme with $K_{\mathrm{i}}$ values in the micromolar range, below the $K_{\mathrm{m}}$ of the enzyme. The most potent inhibitor proved to be the quinazolinedione 15 with a $K_{\mathrm{i}}$ of $19 \mu \mathrm{M}$. This compound clearly stands out from the series as the next ones, specifically compounds 9, 14 and 16, showed $K_{\mathrm{i}}$ values between 77 and 91 $\mu \mathrm{M}$.<smiles>CCC[C@H](NC(=O)NCC(=O)N1c2ccccc2CC[C@H]1C)C(=O)O</smiles><smiles>COc1ccccc1C(=O)Nc1cc(C(=O)O)cc(C(=O)O)c1</smiles><smiles>COc1ccc(Cl)c(C(=O)NC(CCC(=O)O)C(=O)O)c1</smiles>

11<smiles>CCn1cc(C(=O)NCC(=O)NCC(=O)O)c(=O)c2ccc(C)nc21</smiles>

$12{ }^{1} \mathrm{R}=\mathrm{H} ;{ }^{2} \mathrm{R}=\mathrm{CO}_{2} \mathrm{H}$ $13^{1} \mathrm{R}=\mathrm{CO}_{2} \mathrm{H} ;{ }^{2} \mathrm{R}=\mathrm{H}$<smiles>[R]C1([R])C[C@@H](C(=O)NCc2ccc(N3CCCC3=O)cc2)[C@@H](C)C[C@H]1C</smiles><smiles>CC(C)[C@H](NC(=O)Cn1c(=O)[nH]c2ccccc2c1=O)C(=O)O</smiles>

15

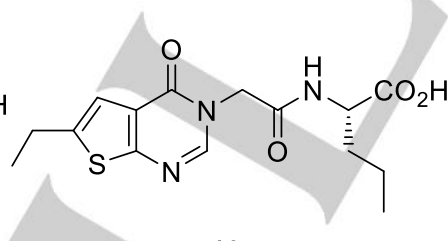

16

Figure 3 Selected potential inhibitors of the Hp-DHQ2 enzyme obtained by the fragment-based approach.

\section{Binding Mode of Compounds 8-16}

The binding modes of the most potent identified inhibitors, compounds 9 and 14-16, revealed that the aromatic ring of the ligands 9 and 14-16 would be located in the interface pocket (Figure 4). The aromatic moiety of compounds 9 and 14-16 should have apolar interactions with the side-chain of Leu93*,
Met92* and the carbon side-chain of Asp89* (residues from this subunit will be marked with an asterisk). The essential Asp89* proved to be responsible for the deprotonation of the essential Tyr22 to afford the catalytic tyrosinate, which in turn triggers the enzymatic process. ${ }^{5}$ Moreover, several lipophilic interactions with the side-chain of Leu11 and Leu14 were also recognized.

The carboxylate group of the inhibitors would be located in the $\mathrm{C} 1$ binding pocket by forming hydrogen-bonding interactions with the side-chain of Asn76, the main amide chain of Leu103 and Thr104. This pocket has been proven to be crucial for substrate recognition and enzyme catalysis. ${ }^{40}$ Thus, the carboxylate group of the natural substrate interacts with the active site through four strong hydrogen bonds involving the main chain NH amide group of Leu103 and Thr104, the $\mathrm{OH}$ group of the side chain of Thr104 side chain and the amide side chain of Asn76 (Figure S1). Moreover, two hydrogen bonds with the conserved Asn76 and His102 is the way in which the enzyme controls the correctly positioning of the $\mathrm{C} 1$ hydroxyl group for the final elimination step.

Table 1. $K_{\mathrm{i}}$ values for compounds 8-16 against $H p-\mathrm{DHQ} 2^{a}$

\begin{tabular}{ll}
\hline Compound & $K_{\mathrm{i}}(\mu \mathrm{M})^{b}$ \\
\hline $\mathbf{8}$ & $141 \pm 19$ \\
$\mathbf{9}$ & $77 \pm 5$ \\
$\mathbf{1 0}$ & $139 \pm 12$ \\
$\mathbf{1 1}$ & $103 \pm 13$ \\
$\mathbf{1 2}$ & $159 \pm 15$ \\
$\mathbf{1 3}$ & $>300$ \\
$\mathbf{1 4}$ & $85 \pm 5$ \\
$\mathbf{1 5}$ & $19 \pm 2$ \\
$\mathbf{1 6}$ & $91 \pm 12$ \\
${ }^{\mathrm{a}}$ Assay conditions: Tris. $\mathrm{HCl}(50 \mathrm{mM}), \mathrm{pH} 7.0,25^{\circ} \mathrm{C}$. \\
$K_{\mathrm{m}}(\mathbf{1})=444 \mu \mathrm{M} .{ }^{b}$ Values are the mean $\pm \mathrm{SEM}$ of $(\mathrm{n}=3)$ \\
determinations.
\end{tabular}

Remarkably, in addition to the above mentioned interactions, the binding modes of the most active inhibitors appear to have in common $\pi-\pi$ stacking and hydrogen-bonding interactions with Tyr22. Specifically, a hydrogen-bond between the phenol group of Tyr22 and the amide carbonyl group of ligand 9 or the carbonyl group of the aromatic ring of ligands 14-16 would take place. Tyr22 is the essential residue that removes the pro- $R$ hydrogen of $\mathrm{C} 2$ in $\mathbf{1}$ and which appropriate orientation for catalysis is controlled by the essential Arg17. This hydrogenbonding interaction with Tyr22 is absent in the weakest inhibitors of the series, ligands $\mathbf{8}$ and $\mathbf{1 0 - 1 2}$, (Figure S2). In addition, the predicted binding of ligands 8 and 12 would be very different from the rest of the tested ligands in this study, which might account for its lower potency. However, in both cases, the aromatic ring of the ligands would be located in the interface pocket. Once the aromatic ring is fixed in this region, the rest of the molecule seems to be located in the space available of the active site by establishing hydrogen-bonding interactions with polar residues of the active site. These results revealed that a large number of the aromatic moieties included in the reported ligands are well located in the interface pocket and might therefore be good hit fragments to be considered in future designs. 
In general: (a) ligand 14 would be the only one lacking any interactions with the C6-C5 substrate recognition center of the enzyme involving the conserved residue His82; (b) the interaction of the aromatic moiety with the essential Tyr22 and the interface pocket in $\mathbf{1 6}$ seems to be less efficient than for compounds 9 and 14-15; and (c) compound 15 would be the ligand that would best interact with the main pockets of the enzyme, which might explain its higher inhibitory potency. Moreover, considering that ligand $\mathbf{9}$ is structurally very close to 3-nitrobenzylgallate-based analogs $\mathbf{7}$, which were reported by Abell et al. ${ }^{11}$ during the realization of the herein presented studies, our subsequent efforts were focused on the optimization of ligand 15.

Globally, the most potent inhibitor identified in this study, compound 15, contains two key moieties: (i) the quinazolinedione ring and (ii) the carboxylate group. Among the two, the aromatic ring seems to be particularly well located to

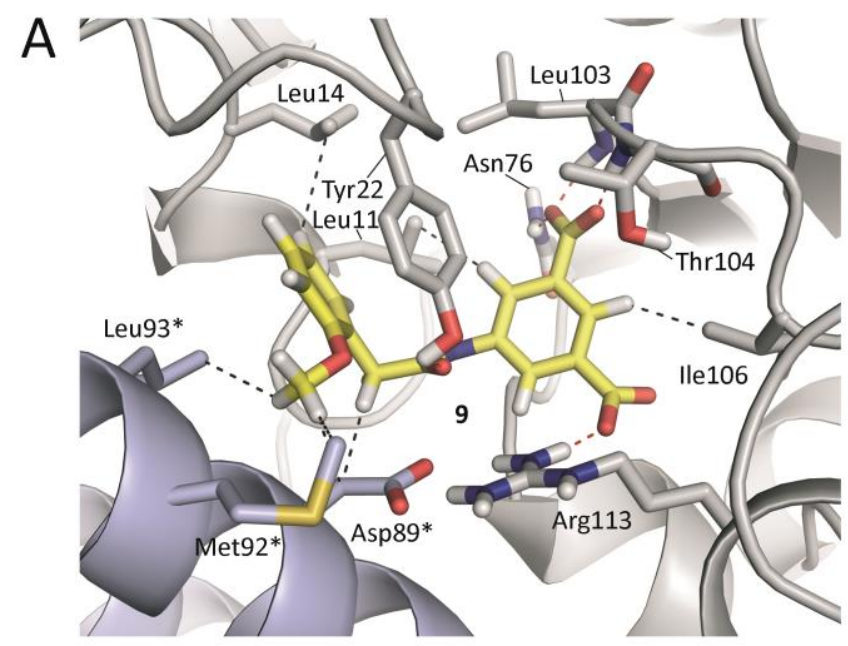

C

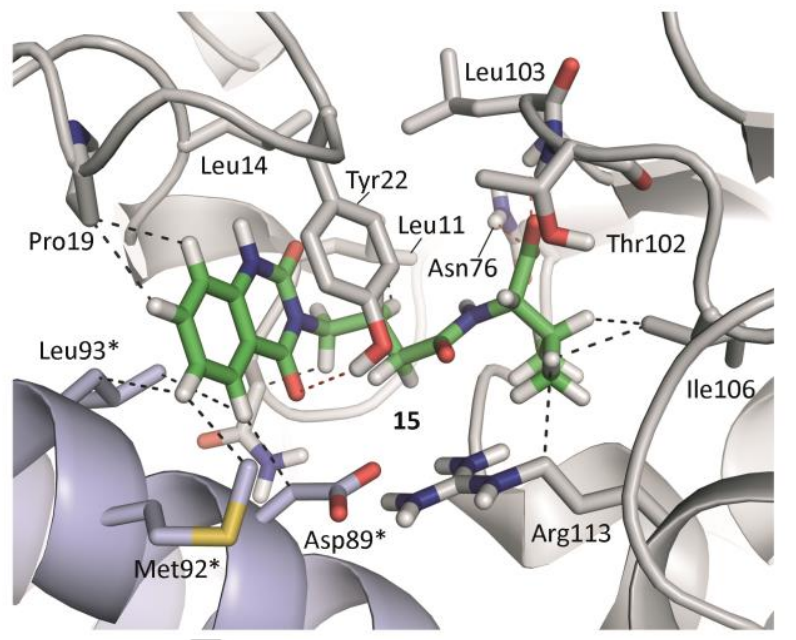

reduce the flexibility of the substrate-covering loop by interaction with the essential tyrosine and the interface pocket. Hence, in order to explore the possible improvement of the inhibitory activity obtained, the modification of the chain containing the carboxylate group in $\mathbf{1 5}$ was then studied.

Four new quinazolinedione derivatives, compounds $17 \mathrm{~S}, 17 R$, and 18-19, were designed (Figure 5A). We took into account the binding mode of citrate in the crystal structure of $\mathrm{Hp}$ DHQ2/citrate binary complex (PDB code $2 \mathrm{C} 4 \mathrm{~V}, 2.5 \AA$ ) reported by Lapthorn et al. ${ }^{41}$ This compound proved to be a competitive inhibitor of the enzyme with a $K_{\mathrm{i}}$ value of $2.5 \mathrm{mM}$. Compounds $17 S$ and $17 R$ containing an acetate group instead of an isopropyl one were designed to improve the interaction with the conserved His82, which is involved in the recognition of the C5 hydroxyl group.
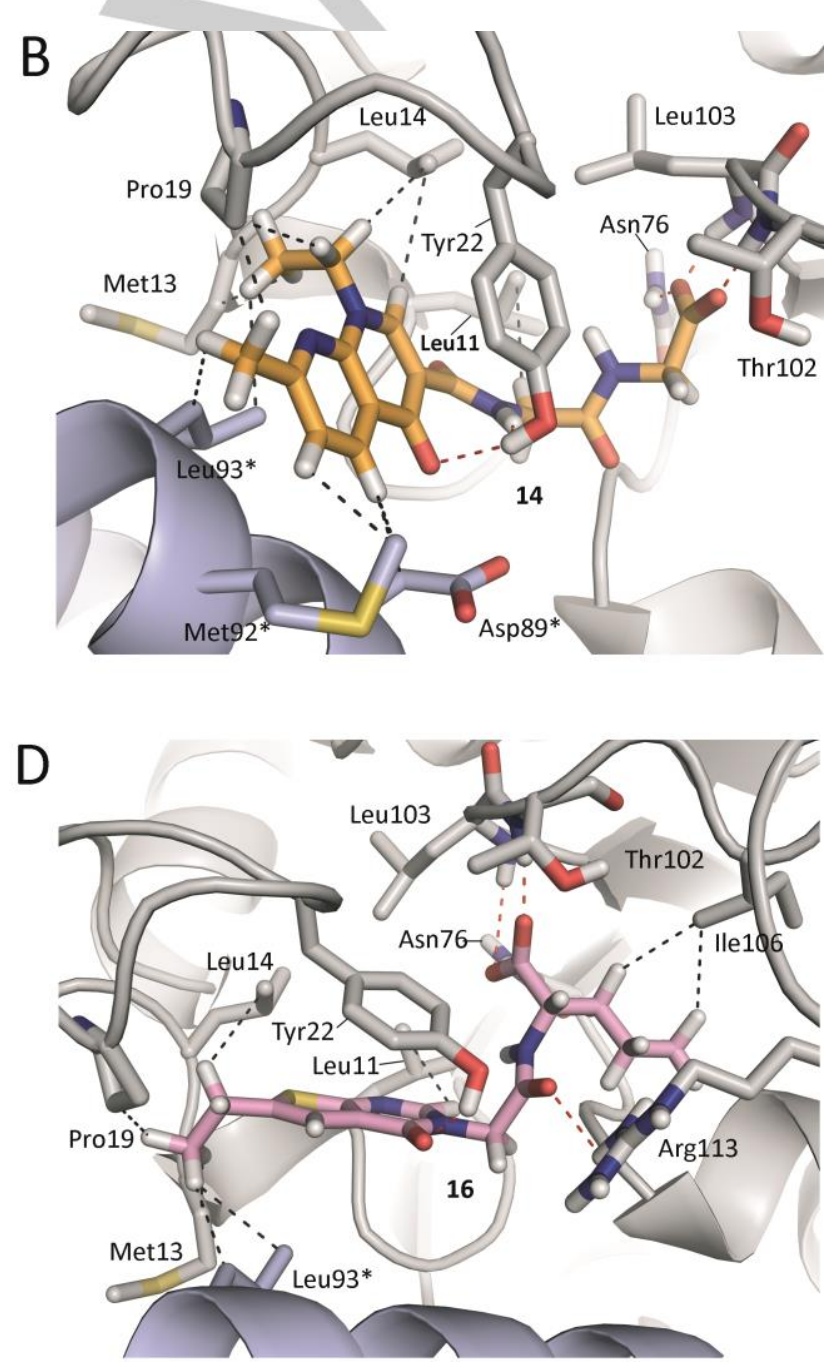

Figure 4 Selected view of the predicted binding mode of ligands: (A) 9 (yellow), (B) 14 (orange), (C) 15 (green), and (D) 16 (pink) in the Hp-DHQ2 active site. The neighboring chain close to the active site is shown in blue and its relevant side chain residues are indicated with an asterisk. Relevant side chain residues are shown and labeled. Hydrogen-bonding (red) and lipophilic (grey) interactions are indicated as dashed lines. 
A
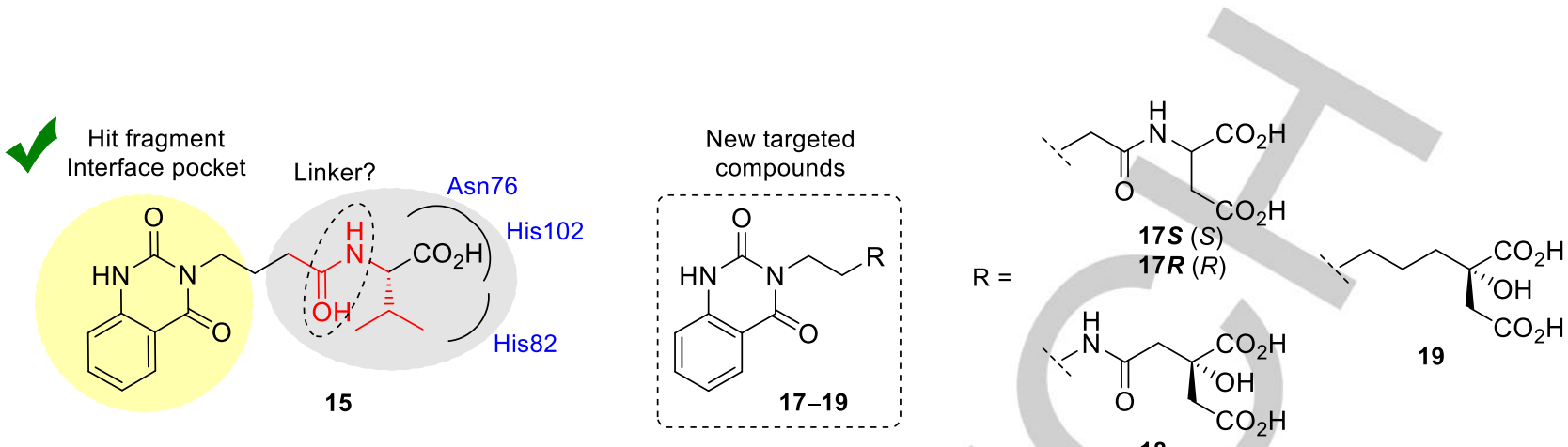

B<smiles>[Z]CCNC(=O)c1ccccc1NNC(=O)C(CCCn1c(=O)[nH]c2ccccc2c1=O)NC(=O)CCCn1c(=O)[nH]c2ccccc2c1=O</smiles>

20

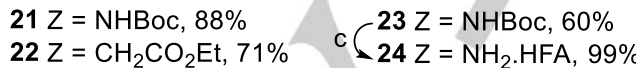

$27 S \mathrm{G}=\mathrm{Me}, 66 \%$

17S G $=\mathrm{H}, 79 \%$<smiles>O=c1[nH]c2ccccc2c(=O)n1CCCl</smiles>

28

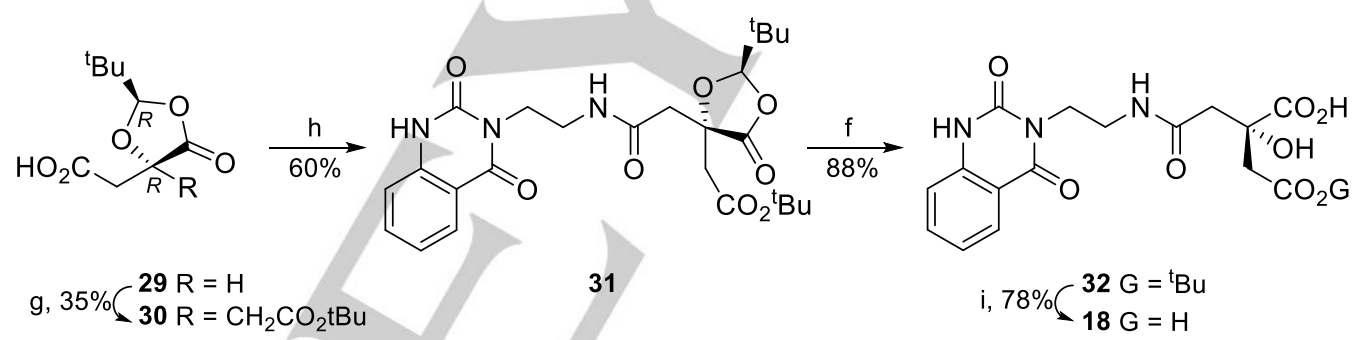

Figure 5 (A) Explored chemical modifications of the carboxylate containing chain in 15. New targeted quinazolinedione derivatives 17-19. (B) Synthesis of compounds 17S, 17R and 18. Reagents and conditions. (a) N-Boc-ethylenediamine (for 21) or ethyl 4-aminobutaroate (for 22), EDC, DMAP, DMF, RT; (b) triphosgene, DIPEA, DCM, RT; (c) TFA, DCM, $0{ }^{\circ} \mathrm{C}$; (d) 1. LiOH, THF, RT. 2. HCl (10\%). (e) 1. SOCl, $60^{\circ} \mathrm{C}$. 2 . Dimethyl L-aspartate (for $27 \mathrm{~S}$ ) or Dimethyl D-

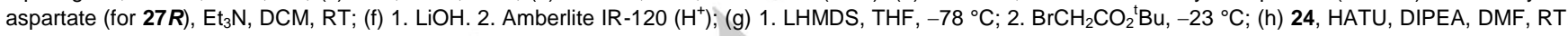
(i) $\mathrm{HCl}(4.5 \mathrm{M}), \mathrm{RT}$.

In addition, reasoning that in the Michaelis complex the $\mathrm{C} 1$ hydroxyl group interacts by hydrogen bonding with the conserved Asn76 and His102 to correctly positioning this group in the final elimination step (Figure S1), ${ }^{5}$ the incorporation of a tertiary hydroxyl group was also explored with compound $\mathbf{1 8}$. Finally, considering that the amide linker does not seem to interact with the enzyme active site residues, the effect of the incorporation of a flexible carbon chain was explored with compound 19.

\section{Chain Optimization - Quinazolinediones derivatives 17-19}

(a) Synthesis - Compounds 17 and 18 were prepared by amide coupling between the acids $\mathbf{2 6}$ and $\mathbf{3 0}$ and the amines dimethyl L-aspartate, dimethyl D-aspartate, and 24, respectively (Figure 5B). Our initial efforts for the synthesis of the aminoquinazolinedione $\mathbf{2 4}$ involved the nucleophilic substitution of commercially available chloride $\mathbf{2 8}$ with lithium amide, sodium azide or benzylamine, various solvents (DMF, MeCN, Toluene), bases $\left(\mathrm{K}_{2} \mathrm{CO}_{3}\right.$, DIPEA) and reaction temperatures $\left(50-100{ }^{\circ} \mathrm{C}\right)$. However, all the attempts afforded mainly starting material or an intramolecular cyclization reaction of $\mathbf{2 8}$. The synthesis of the amino $\mathbf{2 4}$ was finally achieved in three steps from antranilic acid (20) by first incorporation of the required chain followed by quinazolinedione ring formation. Thus, EDC-condensation with commercially available $\mathrm{N}$-Boc-ethylenediamine followed by intramolecular condensation of the resulting amide 21 with triphosgene and subsequent removal of the Boc protecting group in $\mathbf{2 3}$ with TFA yielded the required amine $\mathbf{2 4}$ as trifluoroacetic acid salt. Following a similar strategy, the quinazolinedione $\mathbf{2 6}$ was prepared from ethyl 4-aminobutaroate and antranilic acid (20). 
A<smiles>CCCCCn1c(=O)[nH]c2ccccc2c1=O</smiles>

19<smiles>C=CCn1c(=O)[nH]c2ccccc2c1=O</smiles>

33

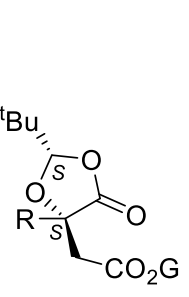

$34 \mathrm{R}=$ allyl, $\mathrm{G}=\mathrm{Me}$ $35 R=G=H$

B

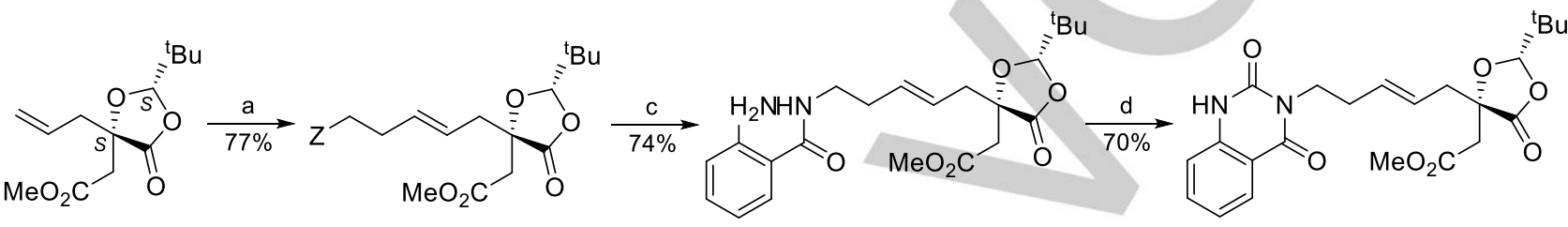

39

Scheme 1 (A) Explored olefin cross metathesis strategy for the synthesis of 19. (B) Synthesis of compound 19. Reagents and conditions. (a) 4-bromobutene, Grubbs-Hoveyda $2^{\text {nd }}$ catalyts, PhMe, $90^{\circ} \mathrm{C}$; (b) $\mathrm{NaN}_{3}$, DMF, $90{ }^{\circ} \mathrm{C}$; (c) 1. Ph $\mathrm{Ph}_{3} \mathrm{THF}, \mathrm{H}_{2} \mathrm{O}, \Delta .2 .20, \mathrm{EDC}, \mathrm{DMAP}, \mathrm{RT}$; (d) triphosgene, Et ${ }_{3} \mathrm{~N}, \mathrm{DCM}, \mathrm{RT}(\mathrm{e}) \mathrm{H}$, Pd/C (10\%), EtOH, RT; (f) 1. LiOH. 2. Amberlite IR-120 ( $\left.\mathrm{H}^{+}\right)$.

On the other hand, the required acid $\mathbf{3 0}$ for the preparation of $\mathbf{1 8}$ was synthesized following Seebach's ${ }^{42}$ self-reproduction of chirality synthetic principle. Thus, alkylation with tert-butyl bromoacetate of the carbanion resulting of the treatment with lithium hexamethylsilazide of previously reported dioxolanone acid $29^{43}$ afforded the desired compound 30 . Next, amide coupling between the acids $\mathbf{2 6}$ and $\mathbf{3 0}$ and the amines dimethyl L-aspartate, dimethyl D-aspartate and 24, respectively, using HATU as coupling agent and in the presence of diisopropylethylamine gave the amides 27S, $27 \boldsymbol{R}$ and 31 , respectively. Finally, deprotection of latter compounds yielded the required amides $17 S, 17 R$ and 18 , respectively.

The synthesis of compound 19, in which the quinazolinedione and the carboxylic acid moieties are linked through a saturated carbon chain, proved to be more challenging. An olefin cross metathesis (OCM) approach involving the construction of the C4-C5 carbon bond was designed (Scheme 1A). This disconnection was chosen because it would allow the use of the allyl derivative $34,{ }^{43}$ which is readily prepared by alkylation with allyl bromide of the dioxolanone acid derived from L-malic acid, compound 35. Initial alkylation attempts revealed that the use of less reactive electrophiles such as long chain alkyl bromides provide quite low yields of the required products.
All the attempts of OCM between the allyl derivatives $\mathbf{3 3}$ and $\mathbf{3 4}$ revealed to be unsatisfactory due to the poor selectivity towards the required heterodimer product. Homodimerization of $\mathbf{3 4}$ was the main reaction product whereas compound $\mathbf{3 3}$ showed to have very low reactivity. Fortunately, the selectivity towards the heterodimer product was achieved following the general guidelines reported by Grubbs et al. ${ }^{44}$ consisting in the use of two olefins of remarkably different reactivity (Scheme 1B). Thus, the OCM between 4-bromobutene (type I olefin) and compound 34 (type II olefin) catalyzed by second generation of GrubbsHoveyda catalysts gave the cross trans olefin $\mathbf{3 6}$ in $71 \%$ yield. Having incorporated the carbon long chain, the following steps were focused in the construction of the quinazolinedione ring. First, the bromide $\mathbf{3 6}$ was converted into the required amine by nucleophilic substitution with sodium azide and subsequent Staudinger reduction of the resulting azide $\mathbf{3 7}$. The EDCcoupling of the terminal amine with antranilic acid $(20)$ in the presence of $4-N, N$-dimethylpyridine gave the amide 38 . It is important to highlight that the presence of a trans double bond in the carbon chain is key for the successful synthesis of the aromatic ring. Thus, the conformational restriction induced by this olefin avoids the intramolecular nucleophilic attack by the resulting amine to the methyl ester. Finally, the intramolecular 
condensation of $\mathbf{3 8}$ with triphosgene gave the quinazolinedione 39 that was transformed into the desired compound 19 by catalytic hydrogenation of the double bond and subsequent hydrolysis of the resulting saturated compound $\mathbf{4 0}$.

(b) Inhibitory activity of compounds 17-19 and 32- The results of inhibition activity of compounds 17-19 and 32 against $\mathrm{Hp}$ DHQ2 revealed that reducing the conformational restriction in the carbon bearing the carboxylic group, which is involved in the recognition in the $\mathrm{C} 1$ pocket, enhances the inhibitory potency (Table 2). The most favorable effect was achieved with compound $19\left(K_{\mathrm{i}}=6.3 \mu \mathrm{M}\right)$ having a flexible carbon chain. In addition, it seems that the increased flexibility also favors extra interactions of the incorporated tertiary hydroxyl and acetate groups with residues Asn76, Leu103, His102 and His82, as designed. In fact, no significant effects were observed when the latter groups were introduced in the ligand having an amide linker, compound 18. In order to corroborate: (1) this hypothesis; (2) to assess the reliability of the proposed complexes and (3) to determine the conformational changes caused in the substratecovering loop of Hp-DHQ2 after compound 19 binding, MD simulations studies were conducted with the highest score solutions obtained by docking for ligands $\mathbf{1 8}$ and 19.

(c) MD Simulations Studies - The binding modes of ligands 18 and 19 were first generated by the program GOLD ${ }^{45}$ version 5.2 using the same enzyme structure as for the fragment docking, i.e., PDB $2 W_{K S}{ }^{9 m}$. The highest score solution for the two $\mathrm{Hp}$ $\mathrm{DHQ} 2 / 18$ and $H p-\mathrm{DHQ} 2 / 19$ binary complexes were subjected to
$100 \mathrm{~ns}$ of MD simulations at a temperature of $300 \mathrm{~K}$ (Figure 6). These studies were carried out considering a dual protonation of His102 based on mechanistic reasons and the three possible protonation states of His82, i.e. dual $(\delta$ and $\varepsilon$ ) and single ( $\delta$ or $\varepsilon$ ). The best results were obtained with a dual protonation of His 82 because in doing so the carboxylate group is well stabilized nearby. Other protonation states provided significant motion on the His82 side chain. In addition, similar results were obtained from MD simulation studies on the Hp-DHQ2/citrate binary complex (PDB code $2 \mathrm{C} 4 \mathrm{~V}$ ). These results explain why in the latter structure the electronegative $\mathrm{O} 4$ atom of one of the carboxylate group in citrate is located at $2.5 \AA$ of the also electronegative NE1 atom of His82 residue.

Table 2. $K_{\mathrm{i}}$ values for compounds $17-19$ and 32 against $H p$ $\mathrm{DHQ}^{a}$

\begin{tabular}{ll}
\hline Compd & $K_{\mathrm{i}}(\mu \mathrm{M})^{b}$ \\
\hline $\mathbf{1 5}$ & $19 \pm 2$ \\
$\mathbf{1 7 S}$ & $111 \pm 3$ \\
$\mathbf{1 7 R}$ & $52 \pm 5$ \\
$\mathbf{1 8}$ & $18 \pm 2$ \\
$\mathbf{1 9}$ & $6.3 \pm 0.2$ \\
$\mathbf{3 2}$ & $166 \pm 15$ \\
\hline
\end{tabular}

${ }^{\mathrm{a}}$ Assay conditions: Tris. $\mathrm{HCl}(50 \mathrm{mM}), \mathrm{pH} 7.0,25^{\circ} \mathrm{C}$

$K_{m}(\mathbf{1})=444 \mu \mathrm{M} ;{ }^{b}$ Values are the mean \pm SEM of $(\mathrm{n}=3)$ determinations.
A
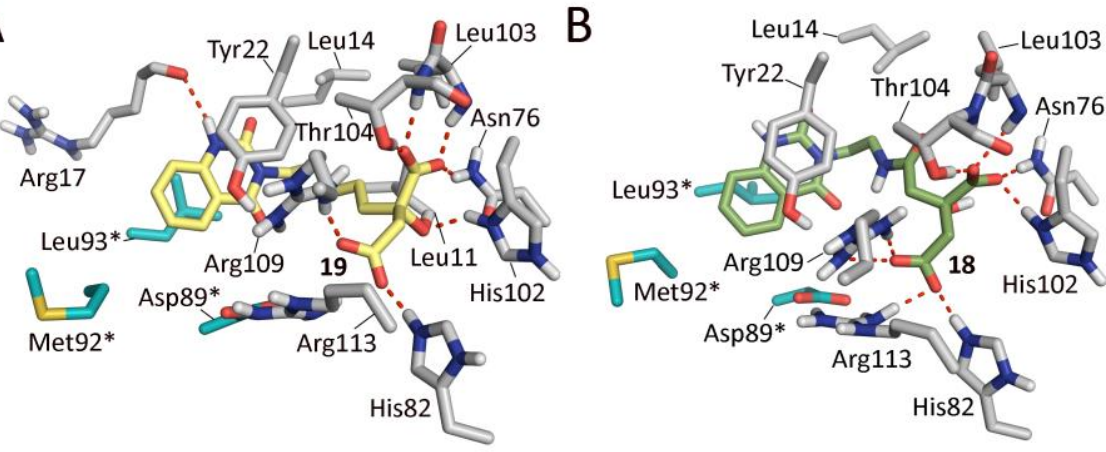

D

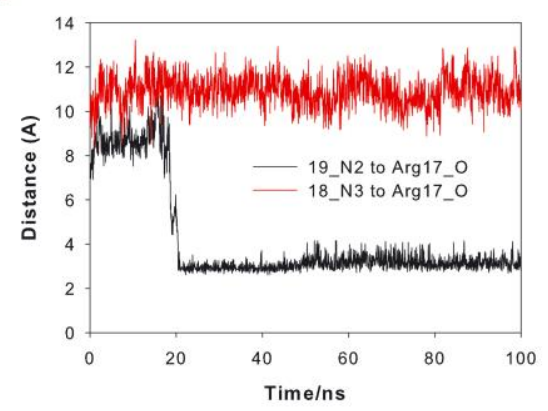

$\mathrm{E}$

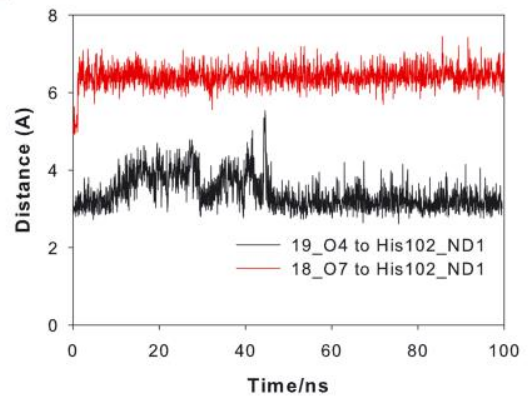

C

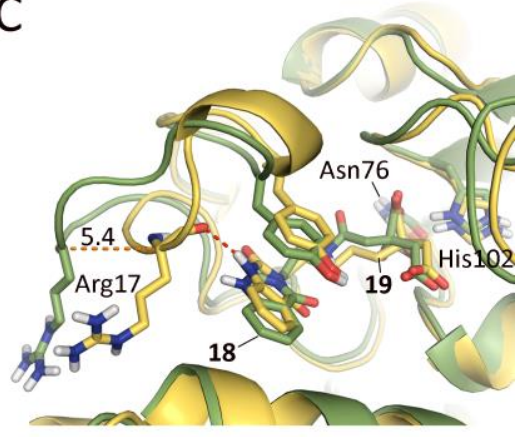

$\mathrm{F}$

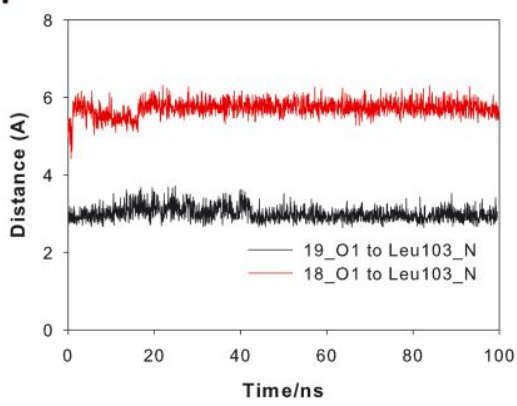

Figure 6 Detailed view of the predicted binding of ligands 19 (A, yellow) and 18 (B, green) in the active site of $H p$-DHQ2 obtained by MD simulation studies. Both poses showed correspond to snapshots after 60 ns of MD simulation. Hydrogen-bonding interactions between ligand and several residues of the active site are shown as red dashes. (C) Comparison of the binding mode of ligands 19 and $\mathbf{1 8}$ in the active site of Hp-DHQ2. (D-F) Variation of the relative distance between resides Arg117 (O atom, D), His102 (ND1 atom, E), and Leu103 (N atom, F) and NH group of the aromatic moiety (N2 and N3 atoms), the medium chain carboxylate (O4, $\mathrm{O} 7$ and $\mathrm{O} 1$ atoms) in 19 and 18, respectively, during the whole simulation. Note how ligand 19 has stronger hydrogen bonding interactions with 
the latter residues than ligand $\mathbf{1 8}$ and provides a closer and more organized conformation of the substrate-covering loop. Side chain residues from the neighbor chain are shown in cyan and labeled with an asterisk.

The results clearly show that the flexible carbon chain in 19: (1) causes a more pronounced reduction of the flexibility of the catalytic loop than in $\mathbf{1 8}$ and (2) enhances the strength of the hydrogen bonding interactions involving residues Asn76, His102, Leu103 and His82. These effects are easily visualized by analyzing the variation of the distance between the atoms involved in these hydrogen bonds during the 100 ns of simulation (Figures 6E-6F and S3). Thus, for ligand 19, the loop folds on top of the ligand so that after 20 ns of simulation a stable hydrogen bond between the $\mathrm{NH}$ group of the aromatic moiety and the backbone carbonyl of Arg17 (in the catalytic loop) is formed with an average distance of $3.1 \AA$ (distances are measured between heavy atoms) (Figures 6C and 6D). In fact, our MD studies revealed that in the presence of 19 the loop is clearly more ordered (Figure 6C). After the folding, the complex is very stable as no significant changes were observed for the remaining simulation (Figure S4A). This phenomenon was not observed for ligand 18, showing an average distance of $10.9 \AA$. The Hp-DHQ2/18 complex remained unchanged during the whole simulation (Figure S4B).

Moreover, the hydrogen bonds between the hydroxyl and carboxylate groups in $\mathbf{1 9}$ with the $\mathrm{NH}$ groups of His102, Asn76 and Leu103 have an average distance of $3.4 \AA$ and $3.0 \AA$, respectively. For 18 , they are $6.4 \AA$ and $5.7 \AA$, respectively. Therefore, the incorporation of the flexible chain in 19 seems to enhance the binding of the carboxylate group of the inhibitor in the $\mathrm{C} 1$ recognition center. The strength of hydrogen bonds involving residue His82 are quite similar (Figure S3). For both ligands, the terminal carboxylate group would interact by favourable electrostatic interactions with the conserved residues Arg109, Arg113 and His82.

\section{Conclusions and Final Remarks}

A multidisciplinary approach has been employed here to search for ligands able to disable the enzyme flexibility that is an essential process for catalysis. This has been applied to the inhibition of a recognized target for antibiotic discovery, the type Il dehydroquinase from Helicobacter pylori (Hp-DHQ2), which is essential enzyme in this pathogenic bacterium. A computeraided fragment-based approach, ALTA, was first employed to identify the aromatic fragment able to block the active site entrance by binding to the interface pocket that separates two neighbor enzyme subunits. The identified quinazolinedione 15 proved to be a reversible competitive of the $H p$-DHQ2 with a $K_{i}$ of $19 \mu \mathrm{M}$, below the $\mathrm{Km}$ of the enzyme $(444 \mu \mathrm{M})$. Subsequent chemical modification of the non-aromatic moiety in $\mathbf{1 5}$ through an olefin cross metathesis and Seebach's self-reproduction of chirality synthetic principle allowed the development of a quinazolinedione derivative containing a flexible malate moiety, compound 19, that seems to efficiently disables the enzyme motion. The latter ligand proved to be more potent with a $K_{\mathrm{i}}$ of $6.3 \mu \mathrm{M}$. The results from our Molecular Dynamics simulation studies revealed that favoring the geometric perfection in anchoring the ligand at the center $\mathrm{C} 1$ recognition center, the motion of the loop would be frozen by the aromatic fragment and consequently the effective inhibition of the enzyme is achieved. This would be accomplished by $\pi-\pi$ stacking interaction between the fragment and the catalytic tyrosine and by hydrogen bonding with the main amide group of the essential arginine. In doing so, the position of both residues would be well fixed in an inappropriate arrangement for catalysis. We also believe that some of the fragments identified in this work might be also useful hit fragments for future designs if the interaction with the $\mathrm{C} 1$ carboxylate pocket is improved.

\section{Experimental Section}

Experimental details on the synthesis of compounds 9-14 are detailed in the supporting information.

2-Amino- $\boldsymbol{N}$-[2-( $\mathrm{N}$-Boc)aminoethyl]benzamide (21) - An stirred solution of antranilic acid (20) (100 mg, $0.73 \mathrm{mmol})$ and $\mathrm{N}$-Boc-ethylenediamine $(0.17 \mathrm{~mL}, 1.09 \mathrm{mmol})$ in dry DMF $(3.6 \mathrm{~mL})$, under argon and at room temperature, was treated with EDC (168 $\mathrm{mg}, 0.87 \mathrm{mmol}$ ) and $\mathrm{N}, \mathrm{N}$ dimethylpyridine $(4.4 \mathrm{mg}, 0.04 \mathrm{mmol}$ ). The resulting mixture was stirred at room temperature for $12 \mathrm{~h}$. The reaction mixture was diluted with ethyl acetate and water. The organic layer was separated and the aqueous phase was extracted with ethyl acetate $(\times 2)$. The combined organic layers were dried (anh. $\mathrm{Na}_{2} \mathrm{SO}_{4}$ ), filtered and concentrated under reduced pressure. The residue obtained was purified by flash chromatography, eluting with $(60: 40)$ ethyl acetate/hexane, to give the amide 21 (179 mg, 88\%) as a white solid. Mp: 163-164 ${ }^{\circ} \mathrm{C}$. ${ }^{1} \mathrm{H}$ NMR (300 $\mathrm{MHz}_{\mathrm{CDCl}}$ ) $\delta: 7.37$ (d, $\left.J=7.8 \mathrm{~Hz}, 1 \mathrm{H}, \mathrm{ArH}\right), 7.22-7.14(\mathrm{~m}, 1 \mathrm{H}, \mathrm{ArH})$, $6.98(\mathrm{br} \mathrm{s}, 1 \mathrm{H}, \mathrm{NH}), 6.63(\mathrm{~m}, 2 \mathrm{H}, 2 \times \mathrm{ArH}), 5.54(\mathrm{br} \mathrm{s}, 2 \mathrm{H}, 2 \times \mathrm{NH}), 5.04(\mathrm{br}$ $\mathrm{s}, 1 \mathrm{H}, \mathrm{NH}), 3.56-3.43\left(\mathrm{~m}, 2 \mathrm{H}, \mathrm{CH}_{2}\right), 3.37\left(\mathrm{~m}, 2 \mathrm{H}, \mathrm{CH}_{2}\right)$ and $1.42(\mathrm{~s}, 9 \mathrm{H}$ $\left.\mathrm{C}\left(\mathrm{CH}_{3}\right)_{3}\right)$ ppm. ${ }^{13} \mathrm{C}$ NMR $\left(75 \mathrm{MHz}, \mathrm{CDCl}_{3}\right) \delta: 170.0(\mathrm{C}), 157.4(\mathrm{C}), 148.9$ $(\mathrm{C}), 132.4(\mathrm{CH}), 127.6(\mathrm{CH}), 117.4(\mathrm{CH}), 116.7(\mathrm{CH}), 115.7(\mathrm{C}), 80.0$ $\left(\mathrm{C}\left(\mathrm{CH}_{3}\right)_{3}\right), 41.5\left(\mathrm{CH}_{2}\right), 40.2\left(\mathrm{CH}_{2}\right)$ and $28.5\left(\mathrm{C}\left(\mathrm{CH}_{3}\right)_{3}\right)$ ppm. IR (ATR) U: $3445(\mathrm{NH}), 3349(\mathrm{NH}), 1674(\mathrm{CO})$ and $1620(\mathrm{CO}) \mathrm{cm}^{-1}$. MS (ESI) $\mathrm{m} / \mathrm{z}$ : $302\left(\mathrm{MNa}^{+}\right)$. HRMS calcd for $\mathrm{C}_{14} \mathrm{H}_{21} \mathrm{~N}_{3} \mathrm{O}_{3} \mathrm{Na}\left(\mathrm{MNa}^{+}\right)$: 302.1475; found, 302.1483 .

Ethyl 4-(2-aminobenzamido)butanoate (22) - A solution of ethyl 4aminobutaroate $(1 \mathrm{~g}, 5.96 \mathrm{mmol})$ and dry triethylamine $(0.9 \mathrm{~mL}, 5.96$ $\mathrm{mmol})$ in dry dichloromethane $(52 \mathrm{~mL})$ and under inert atmosphere was treated at room temperature with EDC $(1.26 \mathrm{~g}, 6.56 \mathrm{mmol})$ and antranilic acid $(20)(2.3 \mathrm{~g}, 11.92 \mathrm{mmol})$ in three portions during $1.5 \mathrm{~h}$. The reaction mixture was washed with aqueous sodium bicarbonate. The organic phase was separated and the aqueous layer was extracted with dichloromethane $(\times 2)$. The combined organic extracts were dried (anh. $\mathrm{Na}_{2} \mathrm{SO}_{4}$ ), filtered and concentrated under reduced pressure. The residue obtained was purified by flash chromatography, eluting with (95:5) dichloromethane/ethyl acetate, to give the amide $22(782 \mathrm{mg}, 71 \%)$ as an orange oil. ${ }^{1} \mathrm{H}$ NMR (250 MHz, $\left.\mathrm{CDCl}_{3}\right) \delta: 7.24$ (dd, $J=7.8$ and $1.5 \mathrm{~Hz}, 1 \mathrm{H}$, ArH), 7.06 (td, $J=1.5$ and $7.0 \mathrm{~Hz}, 1 \mathrm{H}, \mathrm{ArH}), 6.73(\mathrm{br} \mathrm{s}, 1 \mathrm{H}, \mathrm{NH}), 6.55$ (dd, $J=8.1$ and $1.1 \mathrm{~Hz}, 1 \mathrm{H}, \mathrm{ArH}), 6.49(\mathrm{td}, J=1.5$ and $8.0 \mathrm{~Hz}, 1 \mathrm{H}, \mathrm{ArH}), 5.22$ (br s, 2H, NH$H_{2}$ ), 4.00 (q, $J=7.1 \mathrm{~Hz}, 2 \mathrm{H}, \mathrm{OCH}_{2}$ ), 3.30 (q, $J=6.5 \mathrm{~Hz}, 2 \mathrm{H}$, $\mathrm{NCH}_{2}$ ), 2.28 (t, $J=7.1 \mathrm{~Hz}, 2 \mathrm{H}, \mathrm{COCH}_{2}$ ), 1.79 (quint, $J=7.0 \mathrm{~Hz}, 2 \mathrm{H}$, $\mathrm{NCH}_{2} \mathrm{CH}_{2}$ ) and 1.13 (t, $J=7.1 \mathrm{~Hz}, 3 \mathrm{H}, \mathrm{CH}_{3}$ ) ppm. ${ }^{13} \mathrm{C} \mathrm{NMR}(63 \mathrm{MHz}$, 
$\left.\mathrm{CDCl}_{3}\right)$ ঠ: $173.5(\mathrm{C}), 169.4(\mathrm{C}), 148.5(\mathrm{C}), 131.9(\mathrm{CH}), 127.2(\mathrm{CH}), 117.0$ $(\mathrm{CH}), 116.3(\mathrm{CH}), 115.9(\mathrm{C}), 60.4\left(\mathrm{OCH}_{2}\right), 39.0\left(\mathrm{NCH}_{2}\right), 31.7\left(\mathrm{CH}_{2}\right), 24.4$ $\left(\mathrm{CH}_{2}\right)$ and $14.0\left(\mathrm{CH}_{3}\right)$ ppm. IR (ATR) u: $3192(\mathrm{NH}), 1719(\mathrm{CO})$ and 1625 (CO) $\mathrm{cm}^{-1}$. MS (ESI) m/z: $251\left(\mathrm{MH}^{+}\right)$. HRMS calcd for $\mathrm{C}_{13} \mathrm{H}_{19} \mathrm{~N}_{2} \mathrm{O}_{3}\left(\mathrm{MH}^{+}\right)$: 251.1390; found, 251.1385.

3-[2-(N-Boc)aminoethyl]quinazoline-2,4(1H,3H)-dione (23) - A suspension of amide 21 ( $89 \mathrm{mg}, 0.32 \mathrm{mmol}$ ) and triphosgene (47 mg, $0.16 \mathrm{mmol})$ in dry dichloromethane $(1.6 \mathrm{~mL})$, under argon and at room temperature, was treated with DIPEA $(0.1 \mathrm{~mL}, 0.64 \mathrm{mmol})$ and the resultant solution was stirred for $1 \mathrm{~h}$. The reaction mixture was diluted with dichloromethane and saturated aqueous solution of $\mathrm{NaHCO}_{3}$. The aqueous layer was separated and the organic phase was washed with water. The organic extract was dried (anh. $\mathrm{Na}_{2} \mathrm{SO}_{4}$ ), filtered and concentrated under reduced pressure. The residue obtained was purified by flash chromatography, eluting with $(75: 25)$ ethyl acetate/hexane, to give the quinazolinedione 23 (58 mg, 60\%) as a white solid. Mp: 204-205 ${ }^{\circ} \mathrm{C}$. ${ }^{1} \mathrm{H}$ NMR (300 MHz, DMSO-d6) $\delta: 11.35$ (br s, 1H, NH), 7.92 (dd, J = 7.9 and $1.1 \mathrm{~Hz}, 1 \mathrm{H}, \mathrm{ArH}), 7.65-7.60(\mathrm{~m}, 1 \mathrm{H}, \mathrm{ArH}), 7.20-7.14(\mathrm{~m}, 2 \mathrm{H}$ $2 \times \mathrm{ArH}), 6.82(\mathrm{t}, J=5.8 \mathrm{~Hz}, 1 \mathrm{H}, \mathrm{NH}), 3.97\left(\mathrm{t}, J=5.8 \mathrm{~Hz}, 2 \mathrm{H}, \mathrm{CH}_{2}\right), 3.19(\mathrm{t}$ $\left.J=5.8 \mathrm{~Hz}, 2 \mathrm{H}, \mathrm{CH}_{2}\right)$ and $1.28\left(\mathrm{~s}, 9 \mathrm{H}, \mathrm{C}\left(\mathrm{CH}_{3}\right)_{3}\right) \mathrm{ppm} .{ }^{13} \mathrm{C} \mathrm{NMR}(63 \mathrm{MHz}$,

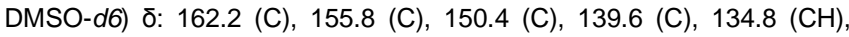
$127.4(\mathrm{CH}), 122.3(\mathrm{CH}), 115.0(\mathrm{CH}), 114.0(\mathrm{C}), 77.5\left(\mathrm{C}\left(\mathrm{CH}_{3}\right)_{3}\right), 40.2$ $\left(\mathrm{CH}_{2}\right), 37.7\left(\mathrm{CH}_{2}\right)$ and $28.2\left(\mathrm{C}\left(\mathrm{CH}_{3}\right)_{3}\right)$ ppm. IR (ATR) u: $3372(\mathrm{NH}), 1703$ (CO), 1671 (CO) and $1648(\mathrm{CO}) \mathrm{cm}^{-1}$. MS (ESI) $\mathrm{m} / \mathrm{z}$ : $328\left(\mathrm{MNa}^{+}\right)$. HRMS calcd for $\mathrm{C}_{15} \mathrm{H}_{19} \mathrm{~N}_{3} \mathrm{O}_{4} \mathrm{Na}\left(\mathrm{MNa}^{+}\right)$: 328.1268; found, 328.1262.

3-(2-Aminoethyl)quinazoline-2,4(1H,3H)-dione trifluoroacetic acid salt (24) - A suspension of protected amine $23(50 \mathrm{mg}, 0.16 \mathrm{mmol})$ in dichloromethane $(1.3 \mathrm{~mL})$ at $0{ }^{\circ} \mathrm{C}$ was treated with TFA $(1.3 \mathrm{~mL})$ and the resultant solution was stirred for $3 \mathrm{~h}$. The reaction mixture was diluted with dichloromethane and water. The organic phase was separated and the aqueous phase was washed with dichloromethane. The aqueous extract was lyophilised to give the amine trifluoroacetic acid salt 24 (50 $\mathrm{mg}, 99 \%)$ as a white solid. $\mathrm{Mp}: 253-255^{\circ} \mathrm{C} .{ }^{1} \mathrm{H}$ NMR $\left(300 \mathrm{MHz}, \mathrm{CD}_{3} \mathrm{OD}\right)$

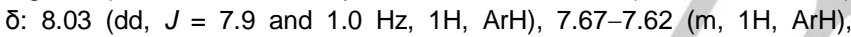
7.20-7.25 (m, 1H, ArH), $7.17(\mathrm{~d}, J=8.2 \mathrm{~Hz}, 1 \mathrm{H}, \mathrm{ArH}), 4.32(\mathrm{t}, J=5.5 \mathrm{~Hz}$, $\left.2 \mathrm{H}, \mathrm{CH}_{2}\right)$ and $3.26\left(\mathrm{t}, J=5.5 \mathrm{~Hz}, 2 \mathrm{H}, \mathrm{CH}_{2}\right) \mathrm{ppm} .{ }^{13} \mathrm{C} \mathrm{NMR}(63 \mathrm{MHz}$, $\left.\mathrm{CD}_{3} \mathrm{OD}\right) \delta$ : $165.3(\mathrm{C}), 153.1(\mathrm{C}), 141.4(\mathrm{C}), 137.0(\mathrm{CH}), 129.3(\mathrm{CH})$, $124.6(\mathrm{CH}), 116.7(\mathrm{CH}), 115.9(\mathrm{C}), 40.4\left(\mathrm{CH}_{2}\right)$ and $39.9\left(\mathrm{CH}_{2}\right)$ ppm. IR (film) u: $3014(\mathrm{NH}), 1720$ (CO), 1687 (CO) and 1654 (CO) $\mathrm{cm}^{-1}$. MS (ESI) $m / z: 204(\mathrm{M}-\mathrm{H})$. HRMS calcd for $\mathrm{C}_{10} \mathrm{H}_{10} \mathrm{~N}_{3} \mathrm{O}_{2}(\mathrm{M}-\mathrm{H}): 204.0779$; found, 204.0782.

Ethyl 3-(2,4-dioxo-1,4-dihydroquinazolin-3(2H)-yl)propanoate (25) A solution of the amine $22(50 \mathrm{mg}, 0.26 \mathrm{mmol})$ and triethylamine $(72 \mu \mathrm{L}$, $0.52 \mathrm{mmol})$ in dry dichloromethane $(1.3 \mathrm{~mL})$, under inert atmosphere and at room temperature, was treated with a solution of triphosgene in dry dichloromethane $(0.3 \mathrm{~mL}, 0.16 \mathrm{mmol}, 0.2 \mathrm{M})$. The resulting solution was stirred for $2 \mathrm{~h}$ and then washed with $\mathrm{HCl}(10 \%, \times 3)$. The aqueous phase was extracted with dichloromethane $(\times 3)$. The combined organic extracts were dried (anh. $\mathrm{Na}_{2} \mathrm{SO}_{4}$ ), filtered and concentrated under reduced pressure. The residue obtained was purified by flash chromatography, eluting with (40:10) diethyl ether/hexane, to give the quinazolinedione 25 (51 mg, 71\%) as a yellow solid. Mp: 270-271 ${ }^{\circ} \mathrm{C} .{ }^{1} \mathrm{H}$ NMR $(250 \mathrm{MHz}$, $\mathrm{CDCl}_{3}$ ) $\delta: 10.85$ (br s, $\left.1 \mathrm{H}, \mathrm{NH}\right), 8.07$ (d, $\left.J=7.8 \mathrm{~Hz}, 1 \mathrm{H}, \mathrm{ArH}\right), 7.61$ (td, $J=$ 1.3 and $8.2 \mathrm{~Hz}, 1 \mathrm{H}, \mathrm{ArH}), 7.20(\mathrm{~m}, 2 \mathrm{H}, 2 \times \mathrm{ArH}), 4.12(\mathrm{t}, J=6.8 \mathrm{~Hz}, 2 \mathrm{H}$, $\mathrm{NCH}_{2}$ ), 4.05 (q, $\left.J=7.1 \mathrm{~Hz}, 2 \mathrm{H}, \mathrm{OCH}_{2}\right), 2.43\left(\mathrm{t}, J=7.5 \mathrm{~Hz}, 2 \mathrm{H}, \mathrm{COCH}_{2}\right.$ ), 2.08 (quint, $J=7.1 \mathrm{~Hz}, 2 \mathrm{H}, \mathrm{NCH}_{2} \mathrm{CH}_{2}$ ) and $1.21\left(\mathrm{t}, J=7.1 \mathrm{~Hz}, 3 \mathrm{H}, \mathrm{CH}_{3}\right.$ ) ppm. ${ }^{13} \mathrm{C}$ NMR $\left(63 \mathrm{MHz}, \mathrm{CDCl}_{3}\right) \delta: 172.8(\mathrm{C}), 162.3(\mathrm{C}), 152.2(\mathrm{C}), 138.5$ (C), $134.9(\mathrm{CH}), 128.1(\mathrm{CH}), 123.2(\mathrm{CH}), 115.1(\mathrm{CH}), 114.4(\mathrm{C}), 60.3$ $\left(\mathrm{OCH}_{2}\right), 40.1\left(\mathrm{NCH}_{2}\right), 31.7\left(\mathrm{CH}_{2}\right), 23.1\left(\mathrm{CH}_{2}\right)$ and $14.0\left(\mathrm{CH}_{3}\right) \mathrm{ppm}$. IR (ATR) U: 2955 (NH), 1729 (CO) and 1620 (CO) $\mathrm{cm}^{-1}$. MS (ESI) m/z: 299
$\left(\mathrm{MNa}^{+}\right)$. HRMS calcd for $\mathrm{C}_{14} \mathrm{H}_{16} \mathrm{~N}_{2} \mathrm{O}_{4} \mathrm{Na}\left(\mathrm{MNa}^{+}\right)$: 299.1002; found, 299.1013.

3-(2,4-dioxo-1,4-dihydroquinazolin-3(2H)-yl)propanoic acid (26) - A solution of the ester $25(200 \mathrm{mg}, 0.73 \mathrm{mmol})$ in dry THF $(1.5 \mathrm{~mL})$ at room temperature was treated with aqueous $\mathrm{LiOH}(2.1 \mathrm{~mL}, 0.7 \mathrm{M})$. The reaction mixture was stirred at room temperature for $2 \mathrm{~h}$ and then washed with diethyl ether. The aqueous phase was acidified with $\mathrm{HCl}$ $(10 \%)$ and extracted with ethyl acetate $(\times 3)$. The combined organic extracts were dried (anh. $\mathrm{Na}_{2} \mathrm{SO}_{4}$ ), filtered and concentrated under reduced pressure to give the acid $26(158 \mathrm{mg}, 90 \%)$ as a white solid. Mp: 247-249 ํ․ ${ }^{1} \mathrm{H}$ NMR (250 MHz, $\left.\mathrm{CD}_{3} \mathrm{OD}\right) \delta: 8.03$ (d, J=7.9 Hz, $\left.1 \mathrm{H}, \mathrm{ArH}\right)$, $7.64(\mathrm{t}, J=7.6 \mathrm{~Hz}, 1 \mathrm{H}, \mathrm{ArH}), 7.23(\mathrm{t}, J=7.6 \mathrm{~Hz}, 1 \mathrm{H}, \mathrm{ArH}), 7.16(\mathrm{~d}, J=$ $8.2 \mathrm{~Hz}, 1 \mathrm{H}, \mathrm{ArH}), 4.09\left(\mathrm{t}, J=6.9 \mathrm{~Hz}, 2 \mathrm{H}, \mathrm{NCH}_{2}\right), 2.39(\mathrm{t}, J=7.3 \mathrm{~Hz}, 2 \mathrm{H}$, $\mathrm{COCH}_{2}$ ) and 1.99 (quint, $\mathrm{J}=7.1 \mathrm{~Hz}, 2 \mathrm{H}, \mathrm{NCH}_{2} \mathrm{CH}_{2}$ ) ppm. ${ }^{13} \mathrm{C} \mathrm{NMR}(63$ $\left.\mathrm{MHz}, \mathrm{CD}_{3} \mathrm{OD}\right) \delta: 176.6(\mathrm{C}), 164.3(\mathrm{C}), 152.3(\mathrm{C}), 140.7(\mathrm{C}), 136.1(\mathrm{CH})$, $128.7(\mathrm{CH}), 123.9(\mathrm{CH}), 116.0(\mathrm{CH}), 115.4(\mathrm{C}), 41.1\left(\mathrm{NCH}_{2}\right), 32.3\left(\mathrm{CH}_{2}\right)$ and $24.3\left(\mathrm{CH}_{2}\right) \mathrm{ppm}$. IR (ATR) u: $3431(\mathrm{NH}+\mathrm{OH}), 1707(\mathrm{CO}), 1688(\mathrm{CO})$ and $1650(\mathrm{CO}) \mathrm{cm}^{-1}$. MS (ESI) $\mathrm{m} / \mathrm{z}$. $247(\mathrm{M}-\mathrm{H})$. HRMS calcd for $\mathrm{C}_{12} \mathrm{H}_{11} \mathrm{~N}_{2} \mathrm{O}_{4}(\mathrm{M}-\mathrm{H}): 247.0724$; found, 247.0721

Diester 275 - A solution of the acid $26(80 \mathrm{mg}, 0.3 \mathrm{mmol})$ in tionyl chloride $(5 \mathrm{~mL})$ was heated under reflux for $30 \mathrm{~min}$. After cooling to room temperature, the solvent was removed under reduced pressure and the crude residue was dissolved in dry dichloromethane $(2 \mathrm{~mL})$ and treated with dry trimethylamine $(80 \mu \mathrm{L}, 0.6 \mathrm{mmol})$ and dimethyl L-aspartate $(60$ $\mathrm{mg}, 0.3 \mathrm{mmol})$. The resulting mixture was stirred at room temperature for $2 \mathrm{~h}$ and then washed with saturated $\mathrm{NaHCO}_{3}(\times 3)$ and brine $(\times 3)$. The organic extract was dried (anh. $\mathrm{Na}_{2} \mathrm{SO}_{4}$ ), filtered and concentrated under reduced pressure. The resulting residue was purified by flash chromatography, eluting with ethyl acetate, to give the diester 275 (78 $\mathrm{mg}, 66 \%)$ as a white foam. $[\alpha]_{\mathrm{D}}^{20}=+27.0^{\circ}\left(c 1.1, \mathrm{CHCl}_{3}\right) .{ }^{1} \mathrm{H}$ NMR $(500$ $\mathrm{MHz}_{\mathrm{CDCl}}$ ) $\delta: 10.01(\mathrm{~s}, 1 \mathrm{H}, \mathrm{NH}), 8.09(\mathrm{dd}, J=0.7$ and $J=7.9 \mathrm{~Hz}, 1 \mathrm{H}$ ArH), $7.60(\mathrm{td}, J=1.4$ and $J=8.2 \mathrm{~Hz}, 1 \mathrm{H}, \operatorname{ArH}), 7.21(\mathrm{t}, J=7.5 \mathrm{~Hz}, 1 \mathrm{H}$, ArH), $7.13(\mathrm{~d}, J=8.1 \mathrm{~Hz}, 1 \mathrm{H}, \mathrm{ArH}), 7.01(\mathrm{br} d, J=8.5 \mathrm{~Hz}, 1 \mathrm{H}, \mathrm{NH}), 4.89$ (dt, $J=4.6$ and $J=8.1 \mathrm{~Hz}, 1 \mathrm{H}, \mathrm{CH}), 4.16\left(\mathrm{~m}, 2 \mathrm{H}, \mathrm{NCH}_{2}\right), 3.73(\mathrm{~s}, 3 \mathrm{H}$, $\mathrm{OCH}_{3}$ ), $3.68\left(\mathrm{~s}, 3 \mathrm{H}, \mathrm{OCH}_{3}\right.$ ), $3.02(\mathrm{dd}, J=4.7$ and $J=17.1 \mathrm{~Hz}, 1 \mathrm{H}$, $\mathrm{CHHCO}_{2} \mathrm{Me}$ ), 2.87 (dd, $J=4.6$ and $J=17.1 \mathrm{~Hz}, 1 \mathrm{H}, \mathrm{CHHCO}_{2} \mathrm{Me}$ ), 2.36 (m, $2 \mathrm{H}, \mathrm{CH}_{2} \mathrm{CO}$ ) and 2.10 (quint, $J=7.0 \mathrm{~Hz}, 2 \mathrm{H}, \mathrm{CH}_{2} \mathrm{CH}_{2} \mathrm{CH}_{2}$ ) ppm. ${ }^{13} \mathrm{C}$ NMR (63 MHz, $\mathrm{CDCl}_{3}$ ) $\delta: 172.2(\mathrm{C}), 171.4(\mathrm{C}), 171.2(\mathrm{C}), 162.5(\mathrm{C})$, $151.7(\mathrm{C}), 138.6(\mathrm{C}), 134.9(\mathrm{CH}), 128.1(\mathrm{CH}), 123.1(\mathrm{CH}), 115.0(\mathrm{CH})$, $114.2(\mathrm{C}), 52.6\left(\mathrm{OCH}_{3}\right), 51.9\left(\mathrm{OCH}_{3}\right), 48.4(\mathrm{CH}), 40.0\left(\mathrm{NCH}_{2}\right), 36.0\left(\mathrm{CH}_{2}\right)$, $33.4\left(\mathrm{CH}_{2}\right)$ and $23.9\left(\mathrm{CH}_{2}\right)$ ppm. IR (ATR) u: $3283(\mathrm{NH}), 1722(\mathrm{CO})$ and 1645 (CO) $\mathrm{cm}^{-1}$. MS (ESI): $392\left(\mathrm{MH}^{+}\right)$. HRMS calcd for $\mathrm{C}_{18} \mathrm{H}_{22} \mathrm{~N}_{3} \mathrm{O}_{7}$ $\left(\mathrm{MH}^{+}\right): 392.1452$; found, 392.1452

Diester 27R - The compound was prepared as its enantiomer 27S using the acid 26 (60 mg, $0.2 \mathrm{mmol})$, tionyl chloride $(3.5 \mathrm{~mL})$, dry dichloromethane $(1.6 \mathrm{~mL})$, dry trimethylamine $(67 \mu \mathrm{L}, 0.4 \mathrm{mmol})$ and dimethyl D-aspartate $(48 \mathrm{mg}, 0.4 \mathrm{mmol})$. Yield $=59 \mathrm{mg}(63 \%$, white foam). The compound has the same NMR data as its enantiomer $27 \mathrm{~S}$. $[\alpha]_{\mathrm{D}}^{20}=-25.0^{\circ}\left(c 1.1, \mathrm{CHCl}_{3}\right)$. MS (ESI): $392\left(\mathrm{MNa}^{+}\right)$. HRMS calcd for $\mathrm{C}_{18} \mathrm{H}_{21} \mathrm{~N}_{3} \mathrm{O}_{7} \mathrm{Na}\left(\mathrm{MNa}^{+}\right)$: 414.1272; found, 414.1268

Diacid 17S - A stirred solution of diester $27 \mathrm{~S}$ (30 $\mathrm{mg}, 0.1 \mathrm{mmol})$ in THF $(1 \mathrm{~mL})$ was treated with $\mathrm{LiOH}(0.3 \mathrm{~mL}, 0.6 \mathrm{mmol}, 2.5 \mathrm{M})$. The resulting mixture was stirred at room temperature for $2 \mathrm{~h}$. The reaction mixture was diluted with water and THF was concentrated under reduced pressure. The aqueous solution was washed with ethyl acetate $(\times 3)$. The aqueous phase was treated with Amberlite IR-120 $\left(\mathrm{H}^{+}\right)$until $\mathrm{pH} 6.0$ and filtered. The filtrate and the washings were freeze-dried to afford compound 17S (22 mg, 79\%) as a white solid. Mp: 165.3-165.7 ${ }^{\circ} \mathrm{C}$. $[\alpha]_{\mathrm{D}}^{20}$ $=+10.2^{\circ}\left(c 0.8, \mathrm{H}_{2} \mathrm{O}\right) .{ }^{1} \mathrm{H}$ NMR $\left(300 \mathrm{MHz}, \mathrm{D}_{2} \mathrm{O}\right) \delta: 7.83(\mathrm{~d}, J=8.0 \mathrm{~Hz}, 1 \mathrm{H}$, ArH), 7.64 (t, $J=7.2 \mathrm{~Hz}, 1 \mathrm{H}, \operatorname{ArH}), 7.23$ (t, $J=7.4 \mathrm{~Hz}, 1 \mathrm{H}, \mathrm{ArH}), 7.06$ (d, 
$J=8.2 \mathrm{~Hz}, 1 \mathrm{H}, \mathrm{ArH}), 4.61(\mathrm{t}, J=5.9 \mathrm{~Hz}, 1 \mathrm{H}, \mathrm{CH}), 3.93(\mathrm{t}, J=7.0 \mathrm{~Hz}, 2 \mathrm{H}$, $\left.\mathrm{NCH}_{2}\right), 2.85\left(\mathrm{~d}, J=6.1 \mathrm{~Hz}, 2 \mathrm{H}, \mathrm{CH}_{2} \mathrm{CO}_{2} \mathrm{H}\right), 2.39(\mathrm{t}, J=7.3 \mathrm{~Hz}, 2 \mathrm{H}$ $\mathrm{CH}_{2} \mathrm{CO}$ ) and 1.95 (quint, $J=7.1 \mathrm{~Hz}, 2 \mathrm{H}, \mathrm{CH}_{2} \mathrm{CH}_{2} \mathrm{CH}_{2}$ ) ppm. ${ }^{13} \mathrm{C} \mathrm{NMR}(63$ $\mathrm{MHz}, \mathrm{D}_{2} \mathrm{O}$ ) $\delta: 177.8$ (C), $177.2(\mathrm{C}), 177.1$ (C), 166.6 (C), 154.1 (C), 140.9 (C), $138.2(\mathrm{CH}), 129.6(\mathrm{CH}), 126.1(\mathrm{CH}), 117.6(\mathrm{CH}), 115.9(\mathrm{C}), 52.0$ $(\mathrm{CH}), 42.8\left(\mathrm{CH}_{2}\right), 38.5\left(\mathrm{CH}_{2}\right), 35.3\left(\mathrm{CH}_{2}\right)$ and $25.5\left(\mathrm{CH}_{2}\right) \mathrm{ppm}$. IR (ATR) U: $3249(\mathrm{OH}+\mathrm{NH}), 1704(\mathrm{CO}), 1644(\mathrm{CO})$ and $1622\left(\mathrm{CO} \mathrm{cm}^{-1}\right.$. MS (ESI): $362(\mathrm{M}-\mathrm{H})$. HRMS calcd for $\mathrm{C}_{16} \mathrm{H}_{16} \mathrm{~N}_{3} \mathrm{O}_{7}(\mathrm{M}-\mathrm{H})$ : 362.0994; found, 362.0993.

Diacid $17 \boldsymbol{R}$ - The compound was prepared as its enantiomer $17 \boldsymbol{R}$ using the diester $27 \boldsymbol{R}(70 \mathrm{mg}, 0.17 \mathrm{mmol})$, THF $(1.8 \mathrm{~mL})$, and $\mathrm{LiOH}(0.34 \mathrm{~mL}$, $2.5 \mathrm{M})$. Yield $=50 \mathrm{mg}(79 \%$, white solid). The compound has the same NMR data as its enantiomer 17S. $[\alpha]_{\mathrm{D}}^{20}=-10.1^{\circ}\left(c 0.8, \mathrm{H}_{2} \mathrm{O}\right)$. MS (ESI): $362(\mathrm{M}-\mathrm{H})$. HRMS calcd for $\mathrm{C}_{16} \mathrm{H}_{16} \mathrm{~N}_{3} \mathrm{O}_{7}(\mathrm{M}-\mathrm{H})$ : 362.0994; found, 362.0994 .

Acid 30 - A solution of 2-((2R,4R)-2-(tert-butyl)-5-oxo-1,3-dioxolan-4yl)acetic acid $(29)^{40}(300 \mathrm{mg}, 1.48 \mathrm{mmol})$ in dry THF $(14.8 \mathrm{~mL})$, under argon and at $-78 \stackrel{\circ}{\circ} \mathrm{C}$, was treated with LHMDS $(2.97 \mathrm{~mL}, 2.97 \mathrm{mmol}$, ca $1 \mathrm{M}$ in THF). After $30 \mathrm{~min}$, a solution of tert-butyl bromoacetate $(0.33 \mathrm{~mL}$, $2.22 \mathrm{mmol})$ in dry THF $(3 \mathrm{~mL})$ was added. The reaction mixture was allowed to warm up to $-23^{\circ} \mathrm{C}$ and it was stirred at this temperature for another $10 \mathrm{~h} . \mathrm{HCl}(1 \mathrm{M})$ was added and the reaction mixture was extracted with ethyl acetate $(\times 3)$. All the organic extracts were dried (anh. $\mathrm{Na}_{2} \mathrm{SO}_{4}$ ), filtered and concentrated under reduced pressure. Purification by flash chromatography, eluting with (91:8:1) dichloromethane/methanol/trimethylamine, gave the ester $30(164 \mathrm{mg}$, $35 \%)$ as a white solid. $[\alpha]_{\mathrm{D}}^{20}=+18^{\circ}\left(c 1.7, \mathrm{CH}_{3} \mathrm{OH}\right) .{ }^{1} \mathrm{H}$ NMR $(250 \mathrm{MHz}$, $\left.\mathrm{CDCl}_{3}\right)$ d: $5.30(\mathrm{~s}, 1 \mathrm{H}, \mathrm{CH}), 3.03(\mathrm{~d}, J=16.1 \mathrm{~Hz}, 1 \mathrm{H}, \mathrm{CHH}), 2.95(\mathrm{~d}, J=$ $15.6 \mathrm{~Hz}, 1 \mathrm{H}, \mathrm{CHH}), 2.87(\mathrm{~d}, J=16.1 \mathrm{~Hz}, 1 \mathrm{H}, \mathrm{CH} H), 2.85(\mathrm{~d}, J=15.6 \mathrm{~Hz}$, $1 \mathrm{H}, \mathrm{CHH}), 1.16\left(\mathrm{~s}, 9 \mathrm{H}, \mathrm{C}\left(\mathrm{CH}_{3}\right)_{3}\right)$ and $0.96\left(\mathrm{~s}, 9 \mathrm{H}, \mathrm{C}\left(\mathrm{CH}_{3}\right)_{3}\right) \mathrm{ppm} .{ }^{13} \mathrm{C}$

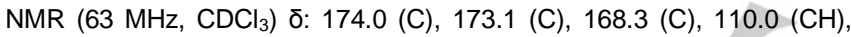

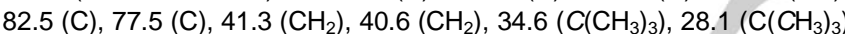
and $23.7\left(\mathrm{C}\left(\mathrm{CH}_{3}\right)_{3}\right) \mathrm{ppm}$. IR $(\mathrm{KBr})$ U: $3009(\mathrm{OH}), 1806(\mathrm{CO}), 1724(\mathrm{CO})$ and $1708(\mathrm{CO}) \mathrm{cm}^{-1}$. MS (ESI) $\mathrm{m} / z$ : $315(\mathrm{M}-\mathrm{H})$. HRMS calcd for $\mathrm{C}_{15} \mathrm{H}_{23} \mathrm{O}_{7}(\mathrm{M}-\mathrm{H})$ : 315.1449; found, 315.1456.

Amide 31 - A stirred solution of acid $30(16 \mathrm{mg}, 0.05 \mathrm{mmol})$ and amine $24(24 \mathrm{mg}, 0.12 \mathrm{mmol})$ in dry DMF $(3.6 \mathrm{~mL})$, under argon and at room temperature, was treated with HATU $(36 \mathrm{mg}, 0.09 \mathrm{mmol})$ and DIPEA $(8.5$ $\mu \mathrm{L}, 0.05 \mathrm{mmol}$ ). The resulting mixture was stirred at room temperature for $1 \mathrm{~h}$. The reaction mixture was diluted with ethyl acetate and water. The organic layer was separated and the aqueous phase was extracted with ethyl acetate $(\times 2)$. The combined organic layers were dried (anh. $\mathrm{Na}_{2} \mathrm{SO}_{4}$ ), filtered and concentrated under reduced pressure. The residue obtained was purified by flash chromatography, eluting with (75:25) ethyl acetate/hexane, to give the amide $\mathbf{3 1}(15 \mathrm{mg}, 60 \%)$ as a white solid. Mp: 203-205 ${ }^{\circ} \mathrm{C} .[\alpha]_{\mathrm{D}}^{20}=+6.7^{\circ}\left(c 1.0, \mathrm{CHCl}_{3}\right) .{ }^{1} \mathrm{H}$ NMR $\left(300 \mathrm{MHz}, \mathrm{CDCl}_{3}\right) \delta:$ 10.3 (br s, $1 \mathrm{H}, \mathrm{NH}), 8.05$ (dd, $J=8.0$ and $1.0 \mathrm{~Hz}, 1 \mathrm{H}, \mathrm{ArH}), 7.68(\mathrm{~m}, 1 \mathrm{H}$ ArH), $7.16(\mathrm{~m}, 2 \mathrm{H}, 2 \times \mathrm{ArH}), 6.94(\mathrm{t}, J=5.0 \mathrm{~Hz}, 1 \mathrm{H}, \mathrm{NH}), 5.26(\mathrm{~s}, 1 \mathrm{H}, \mathrm{CH})$, $4.27\left(\mathrm{t}, J=5.5 \mathrm{~Hz}, 2 \mathrm{H}, \mathrm{CH}_{2}\right), 3.75-3.55\left(\mathrm{~m}, 2 \mathrm{H}, \mathrm{CH}_{2}\right), 2.99(\mathrm{t}, J=16.6 \mathrm{~Hz}$ $1 \mathrm{H}, \mathrm{CHH}), 2.99(\mathrm{~d}, J=16.6 \mathrm{~Hz}, 1 \mathrm{H}, \mathrm{CHH}), 2.89(\mathrm{~d}, J=16.6 \mathrm{~Hz}, 1 \mathrm{H}$, $\mathrm{CHH}), 2.67(\mathrm{~d}, J=14.7 \mathrm{~Hz}, 1 \mathrm{H}, \mathrm{CHH}), 2.60(\mathrm{~d}, J=14.7 \mathrm{~Hz}, 1 \mathrm{H}, \mathrm{CHH})$, $1.41\left(\mathrm{~s}, 9 \mathrm{H}, \mathrm{C}\left(\mathrm{CH}_{3}\right)_{3}\right)$ and $0.89\left(\mathrm{~s}, 9 \mathrm{H}, \mathrm{C}\left(\mathrm{CH}_{3}\right)_{3}\right) \mathrm{ppm} .{ }^{13} \mathrm{C} \mathrm{NMR}(75 \mathrm{MHz}$,

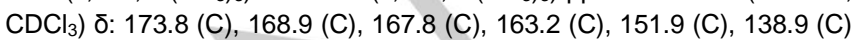
$135.4(\mathrm{CH}), 128.4(\mathrm{CH}), 123.5(\mathrm{CH}), 115.5(\mathrm{CH}), 114.3(\mathrm{C}), 110.2(\mathrm{CH})$,

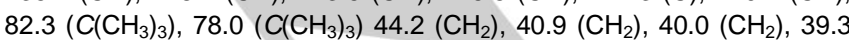
$\left(\mathrm{CH}_{2}\right), 34.5(\mathrm{C}), 28.1\left(\mathrm{C}\left(\mathrm{CH}_{3}\right)_{3}\right)$ and $23.7\left(\mathrm{C}\left(\mathrm{CH}_{3}\right)_{3}\right)$ ppm. IR (ATR) u: $3512(\mathrm{OH}), 3362(\mathrm{NH}), 1793(\mathrm{CO}), 1724(\mathrm{CO})$ and $1659(\mathrm{CO}) \mathrm{cm}^{-1}$. MS (ESI) $\mathrm{m} / \mathrm{z}$. $526\left(\mathrm{MNa}^{+}\right)$. HRMS calcd for $\mathrm{C}_{25} \mathrm{H}_{33} \mathrm{~N}_{3} \mathrm{O}_{8} \mathrm{Na}\left(\mathrm{MNa}^{+}\right)$: 526.2160; found, 526.2168 .
Ester 32 - A stirred solution of ketal $31(40 \mathrm{mg}, 0.08 \mathrm{mmol})$ in water $(0.3$ $\mathrm{mL})$ was treated with $\mathrm{LiOH}(0.7 \mathrm{~mL}, 0.08 \mathrm{mmol}, 0.11 \mathrm{M})$. The resulting mixture was stirred at room temperature for $4 \mathrm{~h}$. The reaction mixture was diluted with ethyl acetate and water. The organic layer was separated and the aqueous phase was washed with ethyl acetate $(\times 2)$. The aqueous phase was treated with Amberlite IR-120 $\left(\mathrm{H}^{+}\right)$until $\mathrm{pH} 6.0$ and filtered. The filtrate and the washings were freeze-dried to afford compound $32(30 \mathrm{mg}, 88 \%)$ as a white solid. Mp: $170{ }^{\circ} \mathrm{C}$ (dec.). $[\alpha]_{\mathrm{D}}^{20}=$ $-0.6^{\circ}$ (c 0.9, $\left.\mathrm{CH}_{3} \mathrm{CN}\right) .{ }^{1} \mathrm{H}$ NMR $\left(300 \mathrm{MHz}, \mathrm{D}_{2} \mathrm{O}\right)$ ס: $7.74(\mathrm{~d}, J=7.9 \mathrm{~Hz}, 1 \mathrm{H}$, ArH), $7.52(\mathrm{t}, J=7.8 \mathrm{~Hz}, 1 \mathrm{H}, \operatorname{ArH}), 7.11(\mathrm{t}, J=7.7 \mathrm{~Hz}, 1 \mathrm{H}, \mathrm{ArH}), 6.96(\mathrm{~d}$, $J=8.2 \mathrm{~Hz}, 1 \mathrm{H}, \operatorname{ArH}), 3.94\left(\mathrm{t}, J=5.7 \mathrm{~Hz}, 2 \mathrm{H}, \mathrm{NCH}_{2}\right), 3.62(\mathrm{t}, J=5.7 \mathrm{~Hz}$, $2 \mathrm{H}, \mathrm{NCH}_{2}$ ), 2.70 (t, $J=15.4 \mathrm{~Hz}, 1 \mathrm{H}, \mathrm{CHH}$ ), $2.51(\mathrm{~d}, J=14.5 \mathrm{~Hz}, 1 \mathrm{H}$ $\mathrm{CHH}), 2.41(\mathrm{~d}, J=15.4 \mathrm{~Hz}, 1 \mathrm{H}, \mathrm{CHH}), 2.37(\mathrm{~d}, J=14.5 \mathrm{~Hz}, 1 \mathrm{H}, \mathrm{CH} H)$ and $1.25\left(\mathrm{~s}, 9 \mathrm{H}, \mathrm{C}\left(\mathrm{CH}_{3}\right)_{3}\right) \mathrm{ppm} .{ }^{13} \mathrm{C}$ NMR $\left(63 \mathrm{MHz}, \mathrm{D}_{2} \mathrm{O}\right) \delta: 172.5(\mathrm{C})$, $171.8(\mathrm{C}), 165.1(\mathrm{C}), 152.5(\mathrm{C}), 139.2(\mathrm{C}), 136.5(\mathrm{CH}), 127.9(\mathrm{CH}), 124.3$ $(\mathrm{CH}), 116.7(\mathrm{C}), 115.9(\mathrm{CH}), 114.1(\mathrm{C}), 83.7(\mathrm{C}), 74.8(\mathrm{C}), 45.6\left(\mathrm{CH}_{2}\right)$,

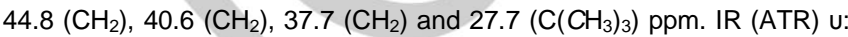
3440,3125 and $3355(\mathrm{OH}+\mathrm{NH}), 1729,1710,1668$ and $1652(\mathrm{CO}) \mathrm{cm}^{-1}$ MS (ESI) $\mathrm{m} / \mathrm{z}$ : 434 (M-H). HRMS calcd for $\mathrm{C}_{20} \mathrm{H}_{24} \mathrm{~N}_{3} \mathrm{O}_{8}(\mathrm{M}-\mathrm{H}): 434.1569$ found, 434.1566 .

Acid 18 - A stirred solution of ester $32(10 \mathrm{mg}, 0.02 \mathrm{mmol})$ in water $(0.11$ $\mathrm{mL}$ ) was treated with aqueous $\mathrm{HCl}(0.08 \mathrm{~mL}, 0.37 \mathrm{mmol}, 4.5 \mathrm{M})$. The resulting mixture was stirred at room temperature for $6 \mathrm{~h}$. The reaction mixture was diluted with ethyl acetate and water. The organic layer was separated and the aqueous phase was washed with ethyl acetate $(\times 2)$. The aqueous phase was freeze-dried to afford the acid $18(7 \mathrm{mg}, 78 \%)$ as a white solid. Mp: $151-152{ }^{\circ} \mathrm{C}$. $[\alpha]_{\mathrm{D}}^{20}=+1.6^{\circ}\left(\mathrm{c} 0.8, \mathrm{H}_{2} \mathrm{O}\right) .{ }^{1} \mathrm{H}$ NMR $\left(500 \mathrm{MHz}, \mathrm{D}_{2} \mathrm{O}\right) \delta: 7.83(\mathrm{~d}, J=8.0 \mathrm{~Hz}, 1 \mathrm{H}, \mathrm{ArH}), 7.56(\mathrm{t}, J=7.7 \mathrm{~Hz}, 1 \mathrm{H}$, ArH), $7.15(\mathrm{t}, J=7.7 \mathrm{~Hz}, 1 \mathrm{H}, \mathrm{ArH}), 7.05(\mathrm{~d}, J=8.3 \mathrm{~Hz}, 1 \mathrm{H}, \mathrm{ArH}), 3.99(\mathrm{~m}$, $\left.2 \mathrm{H}, \mathrm{NCH}_{2}\right), 3.44-3.32\left(\mathrm{~m}, 2 \mathrm{H}, \mathrm{NCH}_{2}\right), 2.77(\mathrm{t}, J=16.1 \mathrm{~Hz}, 1 \mathrm{H}, \mathrm{CHH})$, $2.52(\mathrm{~d}, J=15.3 \mathrm{~Hz}, 2 \mathrm{H}, \mathrm{CH}+\mathrm{CH} H)$ and $1.25(\mathrm{~d}, J=14.6 \mathrm{~Hz}, 1 \mathrm{H}, \mathrm{CHH})$ ppm. ${ }^{13} \mathrm{C}$ NMR (100 MHz, D $\mathrm{O}$ ) ס: 176.4 (C), 173.3 (C), 171.1 (C), 164.3 (C), $151.7(\mathrm{C}), 138.4(\mathrm{C}), 135.7(\mathrm{CH}), 127.1(\mathrm{CH}), 123.6(\mathrm{CH}), 115.1$ $(\mathrm{CH}), 113.3(\mathrm{C}), 73.3(\mathrm{C}), 44.4\left(\mathrm{CH}_{2}\right), 42.6\left(\mathrm{CH}_{2}\right), 39.9\left(\mathrm{CH}_{2}\right)$ and 36.9 $\left(\mathrm{CH}_{2}\right)$ ppm. IR (ATR) U: 3264, 3095, 2917 and $2850(\mathrm{OH}+\mathrm{NH}), 1704$ 1644 and $1622(\mathrm{CO}) \mathrm{cm}^{-1}$. MS (ESI) $\mathrm{m} / \mathrm{z}$ : $378(\mathrm{M}-\mathrm{H})$. HRMS calcd for $\mathrm{C}_{16} \mathrm{H}_{16} \mathrm{~N}_{3} \mathrm{O}_{8}(\mathrm{M}-\mathrm{H})$ : 378.0943 ; found, 378.0942

3-allylquinazoline-2,4(1H,3H)-dione (33) - A suspension of $\mathrm{N}$-allyl-2aminobenzamide $(50 \mathrm{mg}, 0.26 \mathrm{mmol})$, which was prepared as indicated below, in dry dichloromethane $(1.3 \mathrm{~mL})$, under inert atmosphere and at room temperature, was treated with triphosgene $(38 \mathrm{mg}, 0.13 \mathrm{mmol})$ and DIPEA $(0.1 \mathrm{~mL}, 0.052 \mathrm{mmol})$. The resulting solution was stirred for $1 \mathrm{~h}$ and then diluted with dichloromethane and saturated solution of $\mathrm{NaHCO}_{3}$. The aqueous phase was separated and the organic layer was washed with water. The organic extract was dried $\left(\mathrm{anh} . \mathrm{Na}_{2} \mathrm{SO}_{4}\right)$, filtered and concentrated under reduced pressure. The residue obtained was purified by flash chromatography, eluting with $(75: 25)$ ethyl acetate/hexane, to give the quinazolinedione $33(35 \mathrm{mg}, 61 \%)$ as a yellow solid. $\mathrm{Mp}$ :

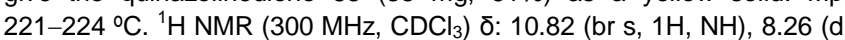
$J=7.9 \mathrm{~Hz}, 1 \mathrm{H}, \mathrm{ArH}), 7.61(\mathrm{t}, J=8.1 \mathrm{~Hz}, 1 \mathrm{H}, \operatorname{ArH}), 7.23(\mathrm{~d}, J=7.9 \mathrm{~Hz}, 1 \mathrm{H}$, ArH), $7.17(\mathrm{t}, J=8.1 \mathrm{~Hz}, 1 \mathrm{H}, \mathrm{ArH}), 5.95-5.82\left(\mathrm{~m}, 1 \mathrm{H} \mathrm{CH}=\mathrm{CH}_{2}\right)$ 5.12-5.01 (m, 2H, CH=CH $), 4.19\left(\mathrm{t}, J=7.1 \mathrm{~Hz}, 2 \mathrm{H}, \mathrm{CH}_{2}\right)$ and $2.51(\mathrm{q}, J=$ $\left.7.1 \mathrm{~Hz}, 2 \mathrm{H}, \mathrm{CH}_{2}\right)$ ppm. ${ }^{13} \mathrm{C}$ NMR $\left(63 \mathrm{MHz}, \mathrm{CDCl}_{3}\right) \delta: 162.3(\mathrm{C}), 152.4(\mathrm{C})$ $138.7(\mathrm{C}), 134.9(\mathrm{C}), 134.8(\mathrm{CH}), 128.3(\mathrm{C}), 123.3(\mathrm{C}), 117.1(\mathrm{C}), 115.1$ (C), $114.6\left(\mathrm{CH}_{2}\right), 40.2\left(\mathrm{CH}_{2}\right)$ and $32.9\left(\mathrm{CH}_{2}\right) \mathrm{ppm}$. IR (ATR) U: $3183(\mathrm{NH})$ 1714 (CO) and 1629 (CO) $\mathrm{cm}^{-1}$. MS (ESI) m/z: $217\left(\mathrm{MH}^{+}\right)$. HRMS calcd for $\mathrm{C}_{12} \mathrm{H}_{13} \mathrm{~N}_{2} \mathrm{O}_{2}\left(\mathrm{MH}^{+}\right)$: 217.0972; found, 217.0969 .

$\mathrm{N}$-allyl-2-aminobenzamide - An stirred solution of antranilic acid (30) $(100 \mathrm{mg}, 0.73 \mathrm{mmol})$ in dry DMF $(3.6 \mathrm{~mL})$, under argon and at room temperature, was treated with EDC $(168 \mathrm{mg}, 0.87 \mathrm{mmol}), \mathrm{N}, \mathrm{N}$ dimethylpyridine $(4.8 \mathrm{mg}, 0.04 \mathrm{mmol})$, DIPEA $(0.25 \mathrm{~mL}, 0.15 \mathrm{mmol})$ and 
3-butenylamine (120 $\mathrm{mg}, 0.11 \mathrm{mmol})$. The resulting mixture was stirred at room temperature for $1 \mathrm{~h}$. The reaction mixture was diluted with ethyl acetate and water. The organic layer was separated and the aqueous phase was extracted with ethyl acetate $(\times 2)$. The combined organic layers were dried (anh. $\mathrm{Na}_{2} \mathrm{SO}_{4}$ ), filtered and concentrated under reduced pressure. The residue obtained was purified by flash chromatography, eluting with $(20: 800)$ ethyl acetate/hexane, to give $N$ allyl-2-aminobenzamide (105 mg, $70 \%$ ) as a white solid. $\mathrm{Mp}: 181-184^{\circ} \mathrm{C}$ ${ }^{1} \mathrm{H}$ NMR $\left(300 \mathrm{MHz}, \mathrm{CDCl}_{3}\right) \delta: 7.28-7.25(\mathrm{~d}, J=7.8 \mathrm{~Hz}, 1 \mathrm{H}, \mathrm{ArH})$, 7.19-7.13 (t, $J=7.7 \mathrm{~Hz}, 1 \mathrm{H}, \mathrm{ArH}), 6.64(\mathrm{~d}, J=8.8 \mathrm{~Hz}, 1 \mathrm{H}, \mathrm{ArH}), 6.59$ (t, $J=8.2 \mathrm{~Hz}, 1 \mathrm{H}, \mathrm{ArH}), 6.27$ (br s, $1 \mathrm{H}, \mathrm{NH}), 5.86-5.72\left(\mathrm{~m}, 1 \mathrm{H}, \mathrm{CH}=\mathrm{CH}_{2}\right)$, $5.48\left(\mathrm{br} \mathrm{s}, 2 \mathrm{H}, \mathrm{NH}_{2}\right), 5.15-5.07\left(\mathrm{~m}, 2 \mathrm{H}, \mathrm{HC}=\mathrm{CH}_{2}\right), 3.44(\mathrm{q}, J=6.4 \mathrm{~Hz}, 2 \mathrm{H}$ $\mathrm{CH}_{2}$ ) and $2.32\left(\mathrm{q}, \mathrm{J}=6.7 \mathrm{~Hz}, 2 \mathrm{H}, \mathrm{CH}_{2}\right) \mathrm{ppm} .{ }^{13} \mathrm{C} \mathrm{NMR}\left(63 \mathrm{MHz}, \mathrm{CDCl}_{3}\right)$ ঠ: $169.2(\mathrm{C}), 148.6(\mathrm{C}), 135.3(\mathrm{C}), 132.1(\mathrm{CH}), 127.1(\mathrm{CH}), 117.3(\mathrm{CH})$, $117.2(\mathrm{CH}), 116.6\left(\mathrm{CH}_{2}\right), 116.3(\mathrm{C}), 38.5(\mathrm{CH})$ and $33.7\left(\mathrm{CH}_{2}\right) \mathrm{ppm}$. IR (ATR) U: $3295(\mathrm{NH})$ and $1616(\mathrm{CO}) \mathrm{cm}^{-1}$. MS (ESI) m/z: $191\left(\mathrm{MH}^{+}\right)$. HRMS calcd for $\mathrm{C}_{11} \mathrm{H}_{15} \mathrm{~N}_{2} \mathrm{O}\left(\mathrm{MH}^{+}\right)$: 191.1179; found, 191.1178 .

Methyl (2S,4S)-2-[(E)-4-(5-bromo-2-pentenyl)-2-(tert-butyl)-5-oxo-1,3dioxolan-4-yl)]acetate (36) - A solution of alkene $34^{43}(160 \mathrm{mg}, 0.62$ $\mathrm{mmol}$ ) and 4-bromobutene $(63 \mu \mathrm{L}, 0.62 \mathrm{mmol})$ in dry toluene $(3 \mathrm{~mL})$ under inert atmosphere was treated with second generation GrubbsHoveyda catalyst $(78 \mu \mathrm{g}, 0.12 \mathrm{mmol})$ and heated at $90{ }^{\circ} \mathrm{C}$ for $16 \mathrm{~h}$. After cooling to room temperature, the reaction mixture was filtered through Celite. The filtrate and the washings were concentrated under reduced pressure and the resulting brown oil was purified by flash chromatography, eluting with (50:50) diethyl ether/hexane, to yield the bromide $36(185 \mathrm{mg}, 77 \%)$ as a yellow oil. $[\alpha]_{\mathrm{D}}^{20}=+2.2^{\circ}\left(c 1.0, \mathrm{CHCl}_{3}\right) .{ }^{1} \mathrm{H}$ $\operatorname{NMR}\left(250 \mathrm{MHz}_{\mathrm{CDCl}}\right)$ ठ: 5.62-5.50 (m, 2H, CH=CH), $5.19(\mathrm{~s}, 1 \mathrm{H}, \mathrm{CH})$, $3.63\left(\mathrm{~s}, 3 \mathrm{H}, \mathrm{OCH}_{3}\right), 3.37\left(\mathrm{t}, \mathrm{J}=6.6 \mathrm{~Hz}, 2 \mathrm{H}, \mathrm{BrCH}_{2}\right), 2.78\left(\mathrm{~s}, 2 \mathrm{H}, \mathrm{CH}_{2} \mathrm{CO}_{2}\right)$ 2.61-2.48 (m, 4H, CH $\left.\mathrm{H}_{2} \mathrm{CH}=\mathrm{CHCH}_{2}\right)$, and $0.90\left(\mathrm{~s}, 9 \mathrm{H}, 3 \times \mathrm{CH}_{3}\right)$ ppm. ${ }^{13} \mathrm{C}$ NMR (63 MHz, $\left.\mathrm{CD}_{3} \mathrm{OD}\right)$ ס: $173.5(\mathrm{C}), 168.6(\mathrm{C}), 133.2(\mathrm{CH}), 124.8(\mathrm{CH})$, $108.1(\mathrm{CH}), 79.9(\mathrm{C}), 51.9\left(\mathrm{OCH}_{3}\right), 39.7\left(\mathrm{CH}_{2}\right), 37.0\left(\mathrm{CH}_{2}\right), 35.5\left(\mathrm{CH}_{2}\right)$, $34.1\left(\mathrm{C}\left(\mathrm{CH}_{3}\right)_{3}\right), 32.1\left(\mathrm{CH}_{2}\right)$ and $23.4\left(3 \times \mathrm{CH}_{3}\right)$ ppm. IR (ATR) U: 1795 (CO) and $1743(\mathrm{CO}) \mathrm{cm}^{-1}$. MS (ESI) $\mathrm{m} / z$ : 385 and $387\left(\mathrm{MNa}^{+}\right)$. HRMS calcd for $\mathrm{C}_{15} \mathrm{H}_{23} \mathrm{Br}^{79} \mathrm{O}_{5} \mathrm{Na}\left(\mathrm{MNa}^{+}\right)$: 385.0621; found, 385.0621

Methyl (2S,4S)-4-[(E)-4-(5-azido-2-pentenyl)]-2-(tert-butyl)-5-oxo-1,3dioxolan-4-yl)acetate (37) - A solution of bromide $36(60 \mathrm{mg}, 0.15$ $\mathrm{mmol}$ ), sodium azide (40 mg, $0.62 \mathrm{mmol}$ ) in dry DMF (4 mL) under inert atmosphere was heated at $90 \stackrel{\circ}{\circ} \mathrm{C}$ for $2 \mathrm{~h}$. After cooling to room temperature, the reaction mixture was diluted with ethyl acetate and water (1:4). The organic layer was separated and the aqueous layer was extracted with ethyl acetate $(\times 3)$. The combined organic extracts were washed with water, dried (anh. $\mathrm{Na}_{2} \mathrm{SO}_{4}$ ), filtered and concentrated under reduced pressure. The resulting residue was purified by flash chromatography, eluting with (50:50) diethyl ether/hexane, to afford the azide 37 (39 mg, 74\%) as a colorless oil. $[\alpha]_{\mathrm{D}}^{20}=+10.4^{\circ}\left(c 1.0, \mathrm{CHCl}_{3}\right) .{ }^{1} \mathrm{H}$

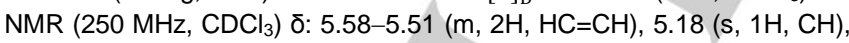
$3.63\left(\mathrm{~s}, 3 \mathrm{H}, \mathrm{OCH}_{3}\right.$ ), $3.29\left(\mathrm{t}, \mathrm{J}=6.6 \mathrm{~Hz}, 2 \mathrm{H}, \mathrm{N}_{3} \mathrm{CH}_{2}\right), 2.77$ (s, 2H, $\mathrm{CH}_{2} \mathrm{CO}_{2}$ ), 2.50-2.48 (m, 2H, CH $\left.\mathrm{H}_{2} \mathrm{CH}\right), 2.34-2.27$ (q, J = $6.2 \mathrm{~Hz}, 2 \mathrm{H}$, $\mathrm{CHCH}_{2}$ ) and $0.91\left(\mathrm{~s}, 9 \mathrm{H}, 3 \times \mathrm{CH}_{3}\right) \mathrm{ppm} .{ }^{13} \mathrm{C} \mathrm{NMR}\left(63 \mathrm{MHz}, \mathrm{CDCl}_{3}\right) \delta$ : $173.4(\mathrm{C}), 168.6(\mathrm{C}), 132.4(\mathrm{CH}), 124.8(\mathrm{CH}), 108.2(\mathrm{CH}), 79.9(\mathrm{C}), 51.9$

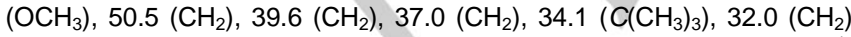
and $23.4\left(3 \times \mathrm{CH}_{3}\right)$ ppm. IR (ATR) U: $2095\left(\mathrm{~N}_{3}\right), 1798$ and $1746(\mathrm{CO}) \mathrm{cm}^{-1}$. MS (ESI) $\mathrm{m} / \mathrm{z}$ : $348\left(\mathrm{MNa}^{+}\right)$. HRMS calcd for $\mathrm{C}_{15} \mathrm{H}_{23} \mathrm{~N}_{3} \mathrm{O}_{5} \mathrm{Na}\left(\mathrm{MNa}^{+}\right)$: 348.1530; found, 348.1530 .

Methyl (2S,4S)-4-[(E)-5-(2-aminobenzamido)-2-pentenyl]-2-(tertbutyl)-5-oxo-1,3-dioxolan-4-ylacetate (38) - A solution of azide 37 (170 $\mathrm{mg}, \quad 0.6 \mathrm{mmol})$ in tetrahydrofuran $(15 \mathrm{~mL})$ was treated with triphenylphosphine $(180 \mathrm{mg}, 0.6 \mathrm{mmol})$ and distilled water $(0.15 \mathrm{~mL})$ and heated under reflux for $12 \mathrm{~h}$. After cooling to room temperature, the solvent was removed under reduced pressure. The resulting crude mixture was dissolved under inert atmosphere in dry dichloromethane $(2.5 \mathrm{~mL})$ and then treated with EDC $(340 \mathrm{mg}, 1.7 \mathrm{mmol})$, DMAP $(53 \mathrm{mg}$ $0.4 \mathrm{mmol}$ ) and anthranilic acid $(20)(130 \mathrm{mg}, 0.4 \mathrm{mmol})$. The resulting mixture was stirred at room temperature for $1 \mathrm{~h}$ and then diluted with dichloromethate and saturated sodium bicarbonate. The aqueous layers were extracted with dichloromethane $(\times 3)$. The combined organic extracts were washed with water, dried (anh. $\mathrm{Na}_{2} \mathrm{SO}_{4}$ ), filtered and concentrated under reduced pressure. The resulting residue was purified by flash chromatography, eluting with (4:1) diethyl ether/ethyl acetate, to give the amide $38(105 \mathrm{mg}, 74 \%)$ as a white foam. $[\alpha]_{\mathrm{D}}^{20}=-5.8^{\circ}(c 1.0$, $\left.\mathrm{CHCl}_{3}\right) .{ }^{1} \mathrm{H}$ NMR $\left(250 \mathrm{MHz}, \mathrm{CDCl}_{3}\right) \delta: 7.35(\mathrm{~d}, J=8.0 \mathrm{~Hz}, 1 \mathrm{H}, \mathrm{ArH}), 7.17$ $(\mathrm{t}, J=7.7 \mathrm{~Hz}, 1 \mathrm{H}, \mathrm{ArH}), 6.67(\mathrm{~d}, J=8.1 \mathrm{~Hz}, 1 \mathrm{H}, \mathrm{ArH}), 6.60(\mathrm{t}, J=7.3 \mathrm{~Hz}$ $1 \mathrm{H}, \mathrm{ArH}), 6.44$ (br s, $1 \mathrm{H}, \mathrm{NH}), 5.66-5.40(\mathrm{~m}, 3 \mathrm{H}, \mathrm{NH}+\mathrm{CH}=\mathrm{CH}), 5.18(\mathrm{~s}$, $1 \mathrm{H}, \mathrm{CH}), 3.63\left(\mathrm{~s}, 3 \mathrm{H}, \mathrm{OCH}_{3}\right), 3.57-3.30\left(\mathrm{~m}, 2 \mathrm{H}, \mathrm{NHCH}_{2}\right), 2.73(\mathrm{~s}, 2 \mathrm{H}$, $\mathrm{CH}_{2} \mathrm{CO}_{2}$ ), 2.50 (d, $\left.J=6.8 \mathrm{~Hz}, 2 \mathrm{H}, \mathrm{NCH}_{2} \mathrm{CH}_{2}\right) 2.32$ (q, J = 6.6 Hz, $2 \mathrm{H}$, $\left.\mathrm{HC}=\mathrm{CHCH}_{2}\right)$, and $0.92\left(\mathrm{~s}, 9 \mathrm{H}, 3 \times \mathrm{CH}_{3}\right) \mathrm{ppm} .{ }^{13} \mathrm{C} \mathrm{NMR}\left(63 \mathrm{MHz} \mathrm{CDCl}_{3}\right) \delta$ : $173.2(\mathrm{C}), 169.2(\mathrm{C}), 168.5(\mathrm{C}), 148.2(\mathrm{C}), 133.8(\mathrm{CH}), 132.0(\mathrm{CH}), 127.1$ $(\mathrm{CH}), 124.0(\mathrm{CH}), 117.2(\mathrm{CH}), 116.7(\mathrm{CH}), 116.0(\mathrm{C}), 107.9(\mathrm{CH}), 80.0$ (C), $51.9\left(\mathrm{OCH}_{3}\right), 39.2\left(\mathrm{CH}_{2}\right), 38.5\left(\mathrm{CH}_{2}\right), 36.6\left(\mathrm{CH}_{2}\right), 34.1\left(\mathrm{C}\left(\mathrm{CH}_{3}\right)_{3}\right)$, $32.6\left(\mathrm{CH}_{2}\right)$ and $23.4\left(3 \times \mathrm{CH}_{3}\right)$ ppm. IR $(\mathrm{ATR}) \mathrm{u}: 3168(\mathrm{NH}), 3096(\mathrm{NH})$, $1773(\mathrm{CO})$ and $1738(\mathrm{CO}) \mathrm{cm}^{-1}$. MS (ESI) m/z: $419\left(\mathrm{MH}^{+}\right)$. HRMS calcd for $\mathrm{C}_{22} \mathrm{H}_{31} \mathrm{~N}_{2} \mathrm{O}_{6}\left(\mathrm{MH}^{+}\right)$: 419.2177 ; found, 419.2180 .

Quinazolinedione 39 - A solution of the aniline $38(40 \mathrm{mg}, 0.1 \mathrm{mmol})$ and triethylamine $(27 \mu \mathrm{L}, 0.2 \mathrm{mmol})$ in dry dichloromethane $(0.5 \mathrm{~mL})$, under inert atmosphere and at room temperature, was treated with a solution of triphosgene $(18 \mathrm{mg}, 0.06 \mathrm{mmol})$ in dry dichloromethane $(0.3$ $\mathrm{mL})$. The reaction mixture was stirred at room temperature for $2 \mathrm{~h}$ and then washed with $\mathrm{HCl}(10 \%, \times 3)$. The combined aqueous layers were extracted with dichloromethane $(\times 3)$. The combined organic extracts were washed with water, dried (anh. $\mathrm{Na}_{2} \mathrm{SO}_{4}$ ), filtered and concentrated under reduced pressure. The resulting residue was purified by flash chromatography, eluting with $(4: 1)$ diethyl ether/ethyl acetate, to afford the quinazolinedione $39(31 \mathrm{mg}, 70 \%)$ as a white foam. $[\alpha]_{\mathrm{D}}^{20}=+5.7^{\circ}$ $\left(c 1.25, \mathrm{CHCl}_{3}\right) .{ }^{1} \mathrm{H} \mathrm{NMR}\left(300 \mathrm{MHz}, \mathrm{CDCl}_{3}\right) \delta: 9.85$ (br s, $\left.1 \mathrm{H}, \mathrm{NH}\right), 8.11$ (d, $J=7.9 \mathrm{~Hz}, 1 \mathrm{H}, \mathrm{ArH}), 7.60$ (td, $J=1.5$ and $7.4 \mathrm{~Hz}, 1 \mathrm{H}, \mathrm{ArH}), 7.22(\mathrm{td}, J=$ 0.9 and $8.0 \mathrm{~Hz}, 1 \mathrm{H}, \mathrm{ArH}), 7.10(\mathrm{~d}, J=8.0 \mathrm{~Hz}, 1 \mathrm{H}, \mathrm{ArH}), 5.71(\mathrm{~m}, 1 \mathrm{H}$ $\mathrm{CH}=\mathrm{CH}), 5.44(\mathrm{~m}, 1 \mathrm{H}, \mathrm{CH}=\mathrm{CH}), 5.11(\mathrm{~s}, 1 \mathrm{H}, \mathrm{CH}), 4.15(\mathrm{t}, \mathrm{J}=7.0 \mathrm{~Hz}, 2 \mathrm{H}$, $\left.\mathrm{NCH}_{2}\right), 3.63\left(\mathrm{~s}, 3 \mathrm{H}, \mathrm{OCH}_{3}\right), 2.76\left(\mathrm{~s}, 2 \mathrm{H}, \mathrm{CH}_{2} \mathrm{CO}_{2}\right), 2.50-2.41(\mathrm{~m}, 4 \mathrm{H}$, $\left.\mathrm{CH}_{2} \mathrm{CH}=\mathrm{CHCH}_{2}\right)$ and $0.87\left(\mathrm{~s}, 9 \mathrm{H}, 3 \times \mathrm{CH}_{3}\right)$ ppm. ${ }^{13} \mathrm{C} \mathrm{NMR}(63 \mathrm{MHz}$,

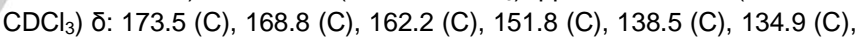
$133.0(\mathrm{CH}), 128.2(\mathrm{CH}), 124.0(\mathrm{CH}), 123.2(\mathrm{CH}), 115.0(\mathrm{CH}), 114.3(\mathrm{C})$, $107.9(\mathrm{CH}), 79.9(\mathrm{C}), 51.8\left(\mathrm{OCH}_{3}\right), 39.9\left(\mathrm{CH}_{2}\right), 39.3\left(\mathrm{CH}_{2}\right), 36.7\left(\mathrm{CH}_{2}\right)$, $34.0\left(\mathrm{C}\left(\mathrm{CH}_{3}\right)_{3}\right), 31.1\left(\mathrm{CH}_{2}\right)$ and $23.4\left(3 \times \mathrm{CH}_{3}\right) \mathrm{ppm}$. IR (ATR) U: $2952(\mathrm{NH})$, 1795 (CO), 1748 (CO), 1717 (CO) and 1659 (CO) $\mathrm{cm}^{-1}$. MS (ESI) m/z: $445\left(\mathrm{MH}^{+}\right)$. HRMS calcd for $\mathrm{C}_{23} \mathrm{H}_{29} \mathrm{~N}_{2} \mathrm{O}_{7}\left(\mathrm{MH}^{+}\right)$: 445.1969; found, 445.1975 .

Quinazolinedione 40 - A solution of the alkene 39 (45 mg, $0.1 \mathrm{mmol})$ in ethanol $(1 \mathrm{~mL})$ under hydrogen atmosphere was added via canula to a suspension of $\mathrm{Pd}-\mathrm{C}(5 \mathrm{mg}, 10 \%)$ in ethanol $(0.5 \mathrm{~mL})$ under hydrogen atmosphere. The resulting suspension was stirred at room temperature for $12 \mathrm{~h}$. Hydrogen was removed under vacuo and the suspension was filtered through a plug of Celite. The filtrate and the washings were concentrated under reduced pressure. The resulting residue was purified by flash chromatography, eluting with ( $4: 1)$ diethyl ether/ethyl acetate, to afford the saturated quinazolinedione $\mathbf{4 0}(38 \mathrm{mg}, 84 \%)$ as a white foam. $[\alpha]_{\mathrm{D}}^{20}=+7.3^{\circ}\left(c 1.25, \mathrm{CHCl}_{3}\right) .{ }^{1} \mathrm{H} \mathrm{NMR}\left(250 \mathrm{MHz}, \mathrm{CDCl}_{3}\right) \delta: 10.20(\mathrm{~s}, 1 \mathrm{H}$, $\mathrm{NH}), 8.12(\mathrm{dd}, J=8.0$ and $1.0 \mathrm{~Hz}, 1 \mathrm{H}, \mathrm{ArH}), 7.63(\mathrm{td}, J=8.5$ and $1.4 \mathrm{~Hz}$, $1 \mathrm{H}, \mathrm{ArH}), 7.24$ (t, $J=7.9 \mathrm{~Hz}, 1 \mathrm{H}, \mathrm{ArH}), 7.13(\mathrm{~d}, J=8.1 \mathrm{~Hz}, 1 \mathrm{H}, \mathrm{ArH})$, $5.16(\mathrm{~s}, 1 \mathrm{H}, \mathrm{CH}), 4.08$ (t, $\left.J=7.2 \mathrm{~Hz}, 2 \mathrm{H}, \mathrm{NCH}_{2}\right), 3.66\left(\mathrm{~s}, 3 \mathrm{H}, \mathrm{OCH}_{3}\right), 2.82$ (s, $\left.2 \mathrm{H}, \mathrm{CH}_{2} \mathrm{CO}_{2}\right), 1.86-1.71\left(\mathrm{~m}, 4 \mathrm{H}, 2 \times \mathrm{CH}_{2}\right)$ and $0.93\left(\mathrm{~s}, 9 \mathrm{H}, 3 \times \mathrm{CH}_{3}\right) \mathrm{ppm}$. ${ }^{13} \mathrm{C}$ NMR $\left(63 \mathrm{MHz}, \mathrm{CD}_{3} \mathrm{OD}\right) \delta: 173.6(\mathrm{C}), 168.5(\mathrm{C}), 162.0(\mathrm{C}), 151.6(\mathrm{C})$, $138.1(\mathrm{C}), 134.7(\mathrm{CH}), 128.0(\mathrm{CH}), 123.1(\mathrm{CH}), 114.6(\mathrm{CH}), 114.2(\mathrm{C})$, 
$107.8(\mathrm{CH}), 79.8(\mathrm{C}), 51.6\left(\mathrm{OCH}_{3}\right), 40.3\left(\mathrm{CH}_{2}\right), 39.2\left(\mathrm{CH}_{2}\right), 33.9\left(\mathrm{CH}_{2}\right)$, $33.2\left(\mathrm{C}\left(\mathrm{CH}_{3}\right)_{3}\right), 27.2\left(\mathrm{CH}_{2}\right), 26.5\left(\mathrm{CH}_{2}\right), 23.2\left(3 \times \mathrm{CH}_{3}\right)$ and $22.6\left(\mathrm{CH}_{2}\right)$ ppm. IR (ATR) u: 2952 (NH), 1790 (CO), 1743 (CO), 1711 (CO) and 1649 (CO) $\mathrm{cm}^{-1}$. MS (ESI) m/z: $447\left(\mathrm{MH}^{+}\right)$. HRMS calcd for $\mathrm{C}_{22} \mathrm{H}_{31} \mathrm{~N}_{2} \mathrm{O}_{7}$ $\left(\mathrm{MH}^{+}\right)$: 447.2126; found, 447.2120 .

Acid 19 - A solution of the diester $40(35 \mathrm{mg}, 0.08 \mathrm{mmol})$ in THF (0.8 $\mathrm{mL}$ ) was treated with aqueous $\mathrm{LiOH}(4.8 \mathrm{~mL}, 0.48 \mathrm{mmol}, 0.1 \mathrm{M})$ and stirred at room temperature for $6 \mathrm{~h}$. The reaction mixture was diluted with ethyl acetate and MilliQ water. The organic layer was separated and the aqueous extract was washed with ethyl acetate $(\times 3)$. The aqueous layer was treated with Amberlite IR-120 $\left(\mathrm{H}^{+}\right)$until $\mathrm{pH} 6$. The filtrate and the washings were lyophilized to give the acid $19(22 \mathrm{mg}, 76 \%)$ as a white solid. $[\alpha]_{\mathrm{D}}^{20}=-14.0^{\circ}\left(c 1.0, \mathrm{H}_{2} \mathrm{O}\right)$. Mp: $177.9-178.1^{\circ} \mathrm{C}$. ${ }^{1} \mathrm{H}$ NMR $(500 \mathrm{MHz}$, $\left.\mathrm{D}_{2} \mathrm{O}\right) \delta: 8.10(\mathrm{~d}, J=8.0 \mathrm{~Hz}, 1 \mathrm{H}, \mathrm{ArH}), 7.83(\mathrm{td}, J=7.9 \mathrm{~Hz}$ and $1.3 \mathrm{~Hz}, 1 \mathrm{H}$, ArH), 7.42 (t, $J=7.7 \mathrm{~Hz}, 1 \mathrm{H}, \mathrm{ArH}), 7.31(\mathrm{t}, J=8.2,1 \mathrm{H}, \mathrm{ArH}), 4.07(\mathrm{t}, J=$ $\left.7.3 \mathrm{~Hz}, 2 \mathrm{H}, \mathrm{NCH}_{2}\right), 3.15(\mathrm{~d}, J=16.3 \mathrm{~Hz}, 1 \mathrm{H}, \mathrm{CHH}), 2.86(\mathrm{~d}, J=16.3 \mathrm{~Hz}$, $1 \mathrm{H}, \mathrm{CHH}), 1.94-1.81\left(\mathrm{~m}, 2 \mathrm{H}, \mathrm{CH}_{2}\right), 1.75\left(\mathrm{q}, J=7.7 \mathrm{~Hz}, 2 \mathrm{H}, \mathrm{CH}_{2}\right), 1.68-$ $1.56(\mathrm{~m}, 1 \mathrm{H}, \mathrm{CHH}), 1.48\left(\mathrm{q}, J=7.6 \mathrm{~Hz}, 2 \mathrm{H}, \mathrm{CH}_{2}\right)$ and $1.44-1.37(\mathrm{~m}, 1 \mathrm{H}$,

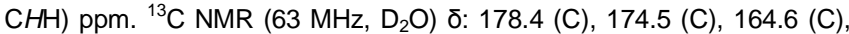
$152.1(\mathrm{C}), 138.8(\mathrm{C}), 136.0(\mathrm{CH}), 127.5(\mathrm{CH}), 123.9(\mathrm{CH}), 115.5(\mathrm{CH})$, $113.9(\mathrm{C}), 75.8(\mathrm{C}), 43.5\left(\mathrm{CH}_{2}\right), 41.2\left(\mathrm{CH}_{2}\right), 38.8\left(\mathrm{CH}_{2}\right), 26.9\left(\mathrm{CH}_{2}\right), 26.3$ $\left(\mathrm{CH}_{2}\right)$ and $22.5\left(\mathrm{CH}_{2}\right)$ ppm. IR (ATR) u: $3325(\mathrm{OH})$ and $1582(\mathrm{CO}) \mathrm{cm}^{-1}$. MS (ESI) m/z: $363(\mathrm{M}-\mathrm{H})$. HRMS calcd for $\mathrm{C}_{17} \mathrm{H}_{19} \mathrm{~N}_{2} \mathrm{O}_{7}(\mathrm{M}-\mathrm{H}): 363.1198$; found, 363.1198 .

\section{Acknowledgements}

Acknowledgements Text. Financial support from the Spanish Ministry of Economy and Competiveness (SAF2013-42899-R and SAF2016-75638-R), the Consellería de Cultura, Educación e Ordenación Universitaria (Centro singular de investigación de Galicia accreditation 2016-2019, ED431G/09) and the European Regional Development Fund (ERDF) is gratefully acknowledged. $A P, A R$ and BB thank the Spanish Ministry of Science and Innovation for their respective FPU and FPI fellowships. We are also grateful to the Centro de Supercomputación de Galicia (CESGA) for use of the Finis Terrae II supercomputer.

Keywords: Enzyme Motion • Inhibitors • Fragment-based • Molecular Dynamics Simulations • Antibiotics

$\delta$ Present address: Department of Biochemistry and Biophysics, University of North Carolina, School of Medicine.

[1] (a) E. D. Brown, G. D. Wright, Nature 2016, 529, 336-343. (b) M. A Fischbach, C. T. Walsh, Science, 2009, 325, 1089-1093. (c) D. Brown, Nature Rev. Drug Discov. 2015, 14, 821-832. (d) M. F. Chellat, L. Raguž, R. Reidl, Angew. Chem. Int. Ed. 2016, 55, 6600-6626. (e) R. J. Fair, Y. Tor, Perspect. Medicin. Chem. 2014, 6, 25-64.

[2] Abell, C. Enzymology and Molecular Biology of the Shikimate Pathway, In: Comprehensive Natural Products Chemistry; Sankawa, U. Ed.; Pergamon, Elsevier Science Ltd.: Oxford, 1999; Vol 1, pp. 573-607.

[3] For a database of essential bacterial genes see www.essentialgene.org.

[4] G. Lamichhane, J. S. Freundlich, S. Ekins, N. Wickramaratne, S. T. Nolan, W. R. Bisha, mBio 2011, 2, e00301.

[5] C. Coderch, E. Lence, A. Peón, H. Lamb, A. R. Hawkins, F. Gago, C. González-Bello, Biochem. J. 2014, 458, 547-557.

[6] J. M. Harris, C. Gonzalez-Bello, C. Kleanthous, A. R. Hawkins, J. R. Coggins, C. Abell, Biochem. J. 1996, 319, 333-336.

[7] C. González-Bello, Curr. Top. Med. Chem. 2016, 16, 960-977.
[8] (a) E. Z. Eisenmesser, M. Akke, D. A. Bosco, D. Kern, Science 2002 295, 1520-1523. (b) S. J. Benkovic, S. Hammes-Schiffer, Science 2003, 301, 1196-1202. (c) M. Garcia-Viloca, J. Gao, M. Karplus, D. G. Truhlar, Science 2004, 303, 186-195. (d) E. Z. Eisenmesser, O. Millet, V. Labeikovsky, D. M. Korzhnev, M. Wolf-Watz, D. A. Bosco, J. J. Skalicky, L. E. Kay, D. Kern, Nature 2005, 438, 117-121. (e) R. Callender, R. B. Dyer, Acc. Chem. Res. 2015, 48, 407-413. (f) P. Hanoian, C. T. Liu, S. Hammes-Schiffer, S. Benkovic, Acc. Chem. Res. 2015, 48, 482-489.

[9] For enolate intermediate mimetics see: (a) M. Frederickson, E.J. Parker, A.R. Hawkins, J.R. Coggins, C. Abell, J. Org. Chem. 1999, 64 2612-2613. (b) M. Frederickson, J.R. Coggins, C. Abell, Chem. Commun. 2002, 1886-1887. (c) C. González-Bello, E. Lence, M.D Toscano, L. Castedo, J.R. Coggins, C. Abell, J. Med. Chem. 2003, 46, 5735-5744. (d) M. Frederickson, A.W. Roszak, J.R. Coggins, A.J. Lapthorn, C. Abell, Org. Biomol. Chem. 2004, 2, 1592-1596. (e) C. Sánchez-Sixto, V.F.V. Prazeres, L. Castedo, H. Lamb, A.R. Hawkins, C González-Bello, J. Med. Chem. 2005, 48, 4871-4881. (f) V.F.V. Prazeres, C. Sánchez-Sixto, L. Castedo, A. Canales, F.J. Cañada, J. Jiménez-Barbero, H. Lamb, A.R. Hawkins, C. González-Bello, ChemMedChem 2006, 1, 990-996. (g) V.F.V. Prazeres, C. SánchezSixto, L. Castedo, H. Lamb, A.R. Hawkins, A. Riboldi-Tunnicliffe, J.R. Coggins, A.J. Lapthorn, C. González-Bello, ChemMedChem 2007, 2, 194-207. (h) M.D. Toscano, R.J. Payne, A. Chiba, O. Kerbarh, C. Abell, ChemMedChem 2007, 2, 101-112. (i) R.J. Payne, A. Riboldi-Tunnicliffe, O. Kerbarh, A.D. Abell, A.J. Lapthorn, C. Abell, ChemMedChem 2007, 2, 1010-1013. (j) R.J. Payne, F. Peyrot, O. Kerbarh, A.D. Abell, C Abell, ChemMedChem 2007, 2, 1015-1029. (k) C. Sánchez-Sixto, V.F.V. Prazeres, L. Castedo, S.W. Shuh, H. Lamb, A.R. Hawkins, F.J. Cañada, J. Jiménez-Barbero, C. González-Bello, ChemMedChem 2008, 3, 756-770. (I) A.T. Tran, K.M. Cergol, W.J. Britton, S.A.I. Bokhari, M. Ibrahim, A.J. Lapthorn, R.J. Payne, Med. Chem. Commun. 2010, 1, 271-275. (m) V.F.V. Prazeres, L. Tizón, J.M. Otero, P. Guardado-Calvo, A.L. Llamas-Saiz, M.J. van Raaij, L. Castedo, H. Lamb, A.R. Hawkins, C. González-Bello, J. Med. Chem. 2010, 53, 191-200. (n) A.T. Tran, K.M. Cergol, N.P. West, E.J. Randall, W.J. Britton, S.A. Bokhari, M. Ibrahim, A.J. Lapthorn, R.J. Payne, ChemMedChem 2011, 6, 262-265. (o) S. Paz, L. Tizón, J.M. Otero, A.L.; Llamas-Saiz, G.C. Fox, M.J. van Raaij, H. Lamb, A.R. Hawkins, A.J. Lapthorn, L. Castedo, C. GonzálezBello, ChemMedChem 2011, 6, 266-272. (p) L. Tizón, J.M. Otero, V.F.V. Prazeres, A.L. Llamas-Saiz, G.C. Fox, M.J. van Raaij, H. Lamb, A.R. Hawkins, J.A. Ainsa, L. Castedo, C. González-Bello, J. Med. Chem. 2011, 54, 6063-6084. (q) B. Blanco, A. Sedes, A. Peón, H. Lamb, A.R. Hawkins, L. Castedo, C. González-Bello, Org. Biomol. Chem. 2012, 10, 3662-3676. (r) B. Blanco, A. Sedes, A. Peón, J.M. Otero, M.J. van Raaij, P. Thompson, A.R. Hawkins, C. González-Bello, J. Med. Chem. 2014, 57, 3494-3510.

[10] For substrate mimetics see: (a) V.F.V. Prazeres, L. Castedo, H. Lamb A. R. Hawkins, C. González-Bello, ChemMedChem 2009, 4, 19801984. (b) A. Peón, J.M. Otero, L. Tizón, V.F.V. Prazeres, A.L. Llamas Saiz, G.C. Fox, M.J. van Raaij, H. Lamb, A.R. Hawkins, F. Gago, L. Castedo, C. González-Bello, ChemMedChem 2010, 5, 1726-1733. (c) L. Lence, L. Tizón, J.M. Otero, A. Peón, V.F.V. Prazeres, A.L. LlamasSaiz, G.C. Fox, M.J. van Raaij, H. Lamb, A.R. Hawkins, C. GonzálezBello, ACS Chem. Biol. 2013, 8, 568-577.

[11] N. I. Howard, M. V. B. Dias, F. Peryot, L. Chen, M. F. Schmidt, T. L. Blundell, C. Abell, ChemMedChem 2015, 10, 116-133.

[12] For examples of crystal structures of the DHQ2 enzyme with an inappropriate arrangement of the substrate-covering loop caused by inhibitor binding see: (a) For $M$. tuberculosis DHQ2: PDB codes $2 \mathrm{XB} 8,{ }^{10 \mathrm{~b}} 2 \mathrm{Y}^{2} 1{ }^{9 \mathrm{p}} 4 \mathrm{~B} 6 \mathrm{Q}^{10 \mathrm{c}}$; (b) For $H$. pylori DHQ2: PDB codes $2 \mathrm{WKS},{ }^{10 \mathrm{~m}} 2 \mathrm{XB9},{ }^{10 \mathrm{~b}} 4 \mathrm{~B} 6 \mathrm{~S}^{10 \mathrm{c}}$

[13] N. C. Price, D. J. Boam, S. M. Kelly, D. Duncan, T. Krell, D. G. Gourley, J. R. Coggins, V. Virden, A. R. Hawkins, Biochem. J. 1999, 338 195-202. 
[14] A. Peón, C. Coderch, F. Gago, C. González-Bello, ChemMedChem 2013, 8, 740-747.

[15] M. V. Dias, W. C. Snee, K. M. Bromfield, R. J. Payne, S. K. Palaninathan, A. Ciulli, N. I. Howard, C. Abell, J. C. Sacchettini, T. L. Blundell, Biochem. J. 2011, 436, 729-739.

[16] C. W. Murray, D. C. Rees, Nature Chem. 2009, 1, 187-192.

[17] R. A. E. Carr, M. Congreve, C. W. Murray, D. C. Rees, Drug Discov. Today 2005, 10, 987-992.

[18] D. C. Rees, M. Congreve, C. W. Murray, R. Carr, Nat. Rev. Drug Discov. 2004, 3, 660-672.

[19] H. L. Silvestre, T. L. Blundell, C. Abell, A. Ciulli, Proc. Natl. Acad. Sci. USA. 2013, 110, 12984-12989.

[20] D. A. Erlanson, R. S. McDowell, T. O'Brien, J. Med. Chem. 2004, 47, 3463-3482.

[21] D. E. Scott, A. G. Coyne, S. A. Hudson, C. Abell, Biochemistry 2012, 51, 4990-5003.

[22] Fragment-based drug discovery: a practical approach, Eds. E. R. Zartler \& M. J. Shapiro, Wiley, Chichester, 2008.

[23] D. Huang, A. Caflisch, Fragment-based approaches in virtual screening: principles, challenges, and Practical Guidelines. Stotriffier, C. Ed. Weinheim, Germany, Wiley, 2011.

[24] M. Congreve, G. Chessari, D. Tisi, A. J. Woodhead, J. Med. Chem. 2008, 51, 3661-3680.

[25] D. Fattori, Drug Discov. Today 2004, 9, 229-238.

[26] M. Congreve, C. W. Murray, T. L. Blundell, Drug Discov. Today 2005, 10, 895-907.

[27] D. Huang, A. Caflisch, J. Mol. Recognit. 2010, 23, 183-193.

[28] P. Kolb, C. B. Kipouros, D. Huang, A. Caflisch, Proteins 2008, 73 11-18.

[29] K. Lafleur, J. Dong, D. Huang, A. Caflisch, C. Nevado, J. Med. Chem 2013, 56, 84-96.

[30] D. Ekonomiuk, X.-C. Su, C. Bodenreider, S. P. Lim, G. Otting, D. Huang, A. Caflisch, J. Med. Chem. 2009, 52, 4860-4568.
[31] P. Schenker, P. Alfarano, P. Kolb, A. Caflisch, A. Baici, Protein Sci. 2008, 17, 2145-2155.

[32] P. Kolb, D. Huang, F. Dey, A. Caflisch, J. Med. Chem. 2008, 51 1179-1188.

[33] D. Spiliotopoulos, A. Caflisch, Drug Discovery Today: Technologies 2016, 19, 81-90.

[34] http://zinc.docking.org

[35] P. Kolb, A. Caflisch, J. Med. Chem. 2006, 49, 7384-7392.

[36] N. Majeux, M. Scarsi, A. Caflisch, Proteins 2001, 42, 256-268.

[37] N. Budin, N. Majeux, A. Caflisch, Biol. Chem. 2001, 382, 1365-1372.

[38] B. R. Brooks, C. L. III Brooks, A. D. J. Mackerell, L. Nilsson, R. J. Petrella, B. Roux, Y. Won, G. Archontis, C. Bartels, S. Boresch, A Caflisch, L. Caves, Q. Cui, A. R. Dinner, M. Feig, S. Fischer, J. Gao, M. Hodoscek, W. Im, K. Kuczera, T. Lazaridis, J. Ma, V. Ovchinnikov, E. Paci, R. W. Pastor, C. B. Post, J. Z. Pu, M. S. Schaefer, B. Tidor, R. M. Venable, H. L. Woodcock, X. Wu, W. Yang, D. M. York, M. Karplus, J. Comput. Chem. 2009, 30, 1545-1614.

[39] D. Huang, A. Caflisch, J. Med. Chem. 2004, 47, 5791-5797.

[40] L. D. B. Evans, A. W. Roszak, L. J. Noble, D. A. Robinson, P. A. Chalk, J. L. Matthews, J. R. Coggins, N. C. Price, A. J. Lapthorn, FEBS Lett. 2002, 530, 24-30

[41] D. A. Robinson, K. A. Stewart, N. C. Price, P. A. Chalk, J. R. Coggins, A. J. Lapthorn, J. Med. Chem. 2006, 49, 1282-1290.

[42] D. Seebach, A. R. Sting, M. Hoffmann, Angew. Chem. Int. Ed. 1996, 35, 2708-2748.

[43] T.-H. N. Nguyen, T.-T. T. Bui, P. V. Pham, D. H. Mac, Tetrahedron Lett. 2016, 57, 216-218.

[44] A. K. Chatterjee, T.-L. Choi, D. P. Sanders, R. H. Grubbs, J. Am. Chem Soc. 2003, 125, 11360-11370.

[45] www.ccdc.cam.ac.uk/products/life_sciences/gold/ 


\section{Entry for the Table of Contents}

\section{FULL PAPER}

A multidisciplinary approach to identify and optimize a quinazolinedione-based ligand that would reduce the flexibility of the substrate-covering loop (catalytic loop) of the type II dehydroquinase from Helicobacter pylori is presented. This enzyme is essential for the survival of this pathogenic bacterium and is involved in the biosynthesis of the aromatic amino acids.

Antonio Peón, Adrián Robles, Beatriz Blanco, Marino Convertino, Paul

Thompson, Alastair R. Hawkins,

Amedeo Caflisch, * and Concepción González-Bello*

Page No. - Page No.

Reducing the Flexibility of Type II

Dehydroquinase Enzyme for Inhibition - A Fragment-Based Approach and Molecular Dynamics Simulation Study
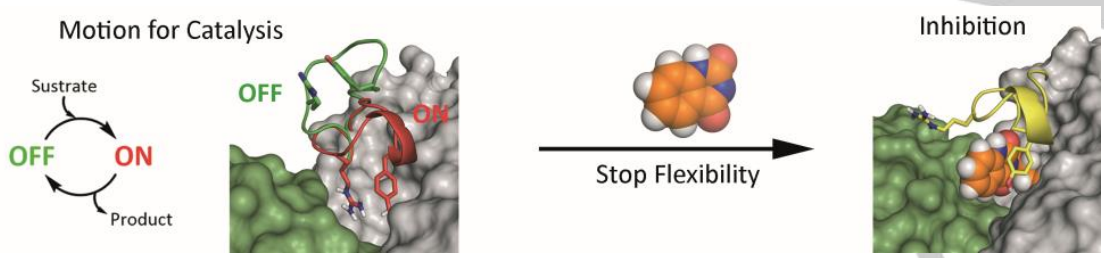